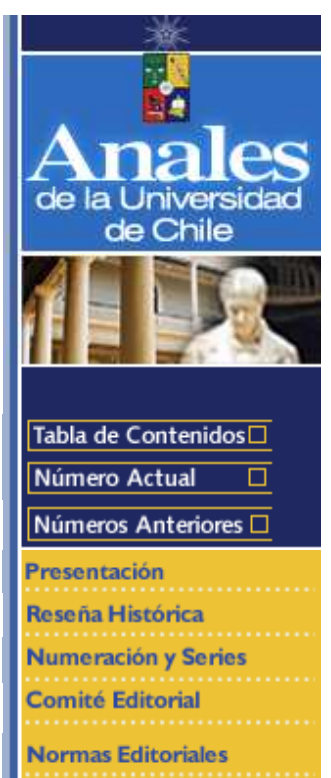

Anales de la Universidad de Chile Sexta Serie, No13, agosto de 2001

Reseña Histónica

Numeración y Series

Normas Editoriales 


\title{
- Estudios
}

\section{[Atacama en el tiempo. territorios, identidades, lenguas.} (Provincia El Loa, II Región).]

\author{
Castro R., Victoria \\ Departamento de Antropología. Facultad de Ciencias \\ Sociales. Universidad de Chile.

\section{RESUMEN} \\ Se ofrece una perspectiva histórica sobre el tema de la \\ construcción de identidades étnicas, desde la época prehispánica \\ hasta el presente etnográfico, en los territorios de costa y tierras \\ altas de la Región de Antofagasta y su dinámica con la vertiente \\ oriental andina aledaña.
}

$\checkmark$ Cita / Referencia

Castro R., Victoria. Atacama en el tiempo. territorios, identidades, lenguas. (Provincia EI Loa, II Región). Anales de la Universidad de Chile, VI serie: No13, Agosto 2001

- http://www2.anales.uchile.cl/CDA/an_completa

/0,1281,SCID\%253D120\%2526ISID\%253D9\%2526ACT\%253D0\%2526PRT\%253D118,00.html

\section{-Territorios}

El territorio que en la Colonia recibió el nombre de Atacama, corresponde actualmente a la Provincia de El Loa, puna aledaña y su franja costera en la región de Antofagasta. Desde el punto de vista cultural, este espacio que fue parte del Kollasuyu de los Inkas, se inserta dentro del Área Centro Sur Andina que comprende ambientes comunes a cuatro países andinos. Los valles occidentales del sur del Perú se prolongan hacia el Norte Grande de Chile y el escaleramiento de pisos costa - puna produce en esencia, situaciones adaptativas similares en el área. Los territorios de tierras altas del norte de nuestro país, participan del enorme paisaje planiforme del altiplano boliviano y el ámbito circumpuneño de Atacama, toca tanto a Bolivia, Chile y Argentina. El límite norte del área, queda definido en la línea esbozada por el río Majes al norte de Arequipa y la subárea circumtitikaka; su límite meridional es una línea ideal dentro del transecto altitudinal que incluye Taltal, Jujuy y tierras orientales inmediatas $^{(1)}$. Las estrategias económicas elegidas por las poblaciones andinas en estas latitudes, señalan como característica fundamental una alta movilidad en tiempos prehispánicos, la que contribuyó a situaciones de cotradición cultural; de hecho se han comprobado nexos entre la región de Omasuyo en el Titikaka y las tierras altas del Loa ${ }^{(2)}$. Cronistas y otras fuente documentales refieren la fuerte interdigitación poblacional que se presenta en esta érea en el momento de la conquista y luego durante la consolidación colonial temprana y que incluye entre otros, a grupos aymara , uru y pukina parlantes ${ }^{(3)}$ Esta situación parece corresponder en parte, a movimientos generados por el principio de ecocomplementariedad andina que incluye tanto desplazamientos verticales, siguiendo la gradiente altitudinal, como horizontales, vinculados a los recursos costeros.

La percepción de esta coherencia cultural y ecológica que permitió a los arqueólogos definir el Área Centro Sur Andina, también fue visualizada por los etnohistoriadores. En este sentido, Saignes, ha definido el bloque geoétnico del Sur compuesto por tres subconjuntos regionales, alineados en largas franjas transversales entre el Pacífico y la Amazonía. Al Norte, el altiplano de la cuenca del Titikaka; el bloque central entre Tarapacá al oeste y el Alto Mamoré al Este que encierran importantes valles como Cochabamba y Chuquisaca, en medio de altas mesetas y sierras y el bloque del Sur, una franja cordillerana que "abarca el desierto costero de Atacama, las punas de Lípez, las serranias y quebradas de Chichas y el Norte de Tucumán hasta la planicie del Chaco". En su concepto, es un vasto conjunto plurilinguístico y multiétnico que ofrece distintos niveles de segmentación social, geográfico y simbólico - los ayllus - muy complejos y poco conocidos ${ }^{(4)}$.

Nos centraremos en la subarea circumpuneña o bloque geoétnico del sur en su vertiente occidental, aunque naturalmente sería imposible dejar de referirse al contexto mayor, especialmente a los territorios de Lípez y Chichas, con los cuales la población de Atacama presenta fuertes vínculos. Jurisdiccionalmente, nos encontramos en el mundo de Charcas colonial. Hacia 1560, las necesidades de la administración regional obligan a la creación de la Audiencia de Charcas, con sede en la ciudad de La Plata o Chuquisaca, cercana a Potosí. La jurisdicción, inicialmente delimitada muy vagamente en unas 100 leguas, comprende diversas zonas complementarias, que comprometen una dinámica de interacción necesaria de apreciar en su conjunto ${ }^{(5)}$.

De acuerdo a las delimitaciones administrativas coloniales, el Corregimiento de Atacama quedo comprendido dentro de la Audiencia de Charcas, con sede en la ciudad de La Plata hasta 1776, fecha en que pasa a formar parte del virreinato de Buenos Aires y a depender directamente de la Intendencia de Potosí. Internamente, el Partido de Atacama fue dividido en Atacama La Alta y Atacama La Baja. La primera tenía como cabecera y doctrina a San Pedro de Atacama y sus ayllus: Condeduque, Sequitur, Solcor, Solor, Coyo y Beter y al oriente del Salar, los asentamientos de Soncor, Toconao, Socaire y Peine; durante el siglo XVIII, se le incorporaron los asentamientos de Susques e Incahuasi, pero de hecho, esta puna aledaña fue siempre parte de Atacama, junto con la localidad de Pastos Grandes, hoy en la puna jujeña. Atacama La Baja comprendia los pueblos de Chiu Chiu 
- como cabeza y doctrina - Ayquina, Caspana, Calama, el asiento de Conchi y localidades de estancias en los pisos altos a partir de los $3000 \mathrm{~m}$ de altitud. En su jurisdicción, quedaba incluida la ensenada de Cobija en la $\operatorname{costa}^{(6)}$.

Inicialmente, a partir de 1534, el espacio atacameño fue percibido como una zona de tránsito hacia el Sur, con una población indigena hostil a los extranjeros ${ }^{(7)}$; no fue sino hasta cerca de 1560 que en este territorio se produjo la instauración jurídica de la paz ${ }^{(8)}$.

\section{- Lenguas, territorios e identidades.}

Históricamente, el concepto de identidad ha estado subsumido en las controversias sobre etnicidad, lenguas y territorios, aún cuando los términos comprenden diferentes extensiones y no tienen por qué presentar una adecuación necesaria entre sí. La identidad, puede significar la noción de pertenencia a un grupo asumiendo la participación de un código cultural compartido, lo que supone una conciencia de las diferencias respecto a otro grupo, sustentándose fuertemente en una memoria colectiva y en una flexibilidad que le otorga la posibilidad de una dinámica de continuidades y cambios. En ese sentido, creemos que la población indígena a la que nos referiremos, ha hecho los arreglos necesarios para seguir teniendo una identidad muchas veces re-creada a través del tiempo ${ }^{(9)}$, lo que obviamente no hace sino complejizar aún más el problema para arqueólogos, etnohistoriadores y etnólogos.

Desde tiempos prehispánicos, las poblaciones indígenas de la Provincia de El Loa han mostrado una dinámica de relaciones que comprende un espacio macroregional, las subáreas circumpuneña y altiplano meridional, que incluyen territorios de los actuales países de Argentina y Bolivia. No es posible entonces percibir a los "atacameños", sin por lo menos esbozar otras probables identidades que están en juego ${ }^{(10)}$.

Nuestros estudios en la Provincia de El Loa, nos han permitido dilucidar que entre los años 800 a 1000 d.C. (inicios del Período Intermedio Tardío o de los Desarrollos Regionales), es posible distinguir, al menos, dos tradiciones culturales: una que hemos denominado "tradición del Desierto" o de "Tierras Áridas" y otra "altiplánica". La primera puede ser identificada con los grupos originarios de la región del Salar de Atacama; la segunda, esta presente en la región del Loa superior y es de clara raigambre altiplánica ${ }^{(11)}$.

En el primer caso, se trataría de la etnia atacameña con una lengua de por sí, que no sería ni aymara ni quechua ${ }^{(12)}$; en el segundo caso, estamos en condiciones de asegurar que se trata de grupos altiplánicos, pero no podemos establecer su lengua. Aunque la primera impresión es que podría tratarse de una etnia aymara parlante, puesto que la actual población de Toconce, Aiquina y Cupo tiene apellidos aymara y abundan los topónimos y nombres de flora y fauna en esa lengua, median cinco siglos de alta complejidad de acuerdo a las informaciones etnohistóricas; sobre todo si se considera que algunas fuentes del siglo XVI, hacen referencia a varios grupos étnicos y al uso, al menos, de cuatro lenguas: aymara, quechua, puquina y uroquilla, interdigitadas en la subárea altiplano meridional ${ }^{(13)}$. Adicionalmente, consideramos riesgoso en la mayoría de los casos establecer una equivalencia directa entre identidades y lenguas, especialmente en zonas de gran permeabilidad del tramado étnico, aspecto sobre el que volveremos más adelante.

Tradicionalmente, la región del Loa Superior fue vinculada a los desarrollos culturales atacameños. Fue a fines de la década de los setenta ${ }^{(14)}$, que pudimos sostener que los ocupantes del sitio arqueológico de Likan en Toconce, procedían de poblaciones originarias de la región de Omasuyo en la vertiente oriental del lago Titikaka. Sin embargo, esta población altiplánica, contenía entre sus ofrendas funerarias elementos atacameños. ¿se trataría de "atacameños altiplanizados"? ¿Por qué su configuración interna distintiva era tan diferente? ¿Cómo dilucidar este aparente problema de identidades?

El hallazgo de varios otros sitios con características similares a Likan en diversas localidades de la cuenca del río Salado, muestra claramente la distribución subregional alcanzada por esta población que arqueológicamente denóminamos fase Toconce, una sociedad de pastores - agricultores que hacia los años 800 D.C., irrumpen en la prehistoria regional y que en nuestro concepto es "altiplánica" al menos en dos sentidos: en primer lugar, porque sus más remotos orígenes estarían en el altiplano septentrional a orillas del lago Titikaka y en segundo lugar, porque formó parte de una sociedad cuyo territorio comprendía tanto las quebradas altas del río Salado, como la sección meridional del altiplano de Lípez ${ }^{(15)}$

A mediados de la década de los ochenta, estuvimos en condiciones de discutir como las investigaciones arqueológicas fueron desechando la supuesta "filiación atacameña" de algunos sitios del Período Intermedio Tardío en el Loa Superior, en favor de una filiación "altiplánica"(16), aspecto que sin duda y dentro de una perspectiva histórica, toca al problema de las identidades.(17)

La movilidad tan característica de los pueblos del Área Centro sur Andina, generó una variada interdigitación de unidades étnicas que tendieron a cristalizar un patrón de complementariedad económica, social y política, el que pusieron en práctica a través de múltiples mecanismos ${ }^{(18)}$. En términos arqueológicos, esta realidad se expresa en un mosaico de fases culturales sincronicas cuyas experiencias comparten identidades y diferencias, plasmadas materialmente en sus artes y técnicas ${ }^{(19)}$. En Atacama, representan a la población de esta época las Fases Solor y Lasana II, de la tradición del Desierto y el Complejo Toconce-Mallku, de la tradición altiplánica. Dentro de los elementos que parecen compartir todas estas poblaciones del Período Intermedio Tardío en la subárea circumpuneña, destaca un patrón arquitectónico defensivo, localizados entre los 2500 y 3000 m de altitud; las aldeas no defensivas son aglutinadas, con habitaciones, corrales, depósitos para almacenaje y en la periferia, campos de cultivo y canales de regadío. Hay una amplia gama en el patrón constructivo funerario, pero en todos los casos, el ofertorio funerario comprende cestería, semillas de algarrobo y frutos de chañar, calabazas pirograbadas, elementos del complejo para el uso de plantas psicoactivas, artefactos vinculados con el trabajo textil, alfarería y prácticas de deformación craneana. Hay presencia de cerámicas de amplia distribución regional y otras provenientes de la subárea circumtitikaka, altiplano meridional y noroeste argentino que denotan relaciones 
entre diferentes pueblos; la arqueología permite deducir una económia agropecuaria floreciente y una alta movilidad interregional.

En cuanto a las situaciones de conflicto latentes o manifiestas, éstas se expresan en los asentamientos defensivos, el arte rupestre y los contextos funerarios ${ }^{(20)}$. Es interesante constatar la perduración iconográfica de una representación pan andina - la figura del Sacrificador, que porta en una de sus manos un hacha y en la otra una cabeza cortada - , asociada a tabletas y tubos para el consumo de psicoactivos, que se han encontrado distribuidas en este período en Calama, Caspana, Toconce y San Pedro de Atacama. También este motivo está representado en el arte rupestre de la región, de manera que podría estar significando algún tipo de prácticas chamánicas $^{(21)}$

El registro arqueológico de la fase Solor de San Pedro de Atacama, evidencia un traslape de unos 300 años en el que se presentan derivaciones del período anterior con estilística Tiwanaku. Durante el desarrollo de esta fase, disminuyen paulatinamente los elementos del "complejo alucinógeno" y aumentan las calabazas pirograbadas con motivos figurativos o geométricos. Entre los primeros hay representaciones de ofidios muy similares a los dibujados en la cerémica y placas de bronce santamarianas, un desarrollo sincrónico del noroeste argentino; también son frecuentes los diseños de grandes espirales y separación diagonal de campos, propios de la alfarería Yavi del noroeste argentino.

Se puede asegurar que los grupos de la tradición del Desierto durante el Período Intermedio Tardío, interactuaron muy fuertemente con poblaciones asentadas en lugares distantes y accedieron a bienes de todo el transecto costa- altiplano, pero aparentemente, sus fuertes vínculos con la subárea circumtitikaka, tan característicos del período anterior, se diluyeron. No obstante, reforzaron sus relaciones con el noroeste argentino y el altiplano meridional de Bolivia, nexos que seguirán siendo evidentes en la época incaica y colonial indígena ${ }^{(22)}$

El complejo Lasana de la Tradición del desierto, que agruparia a poblaciones de oasis como Chiuchiu y Calama y, en parte, a la gente de las localidades de Topaín y Turi hacia los 3000 metros en la cuenca del río Salado, es mucho menos conocido; lo mas característico de esta fase, es que comparte rasgos tanto de la tradición del Desierto como de la altiplánica, con ciertas particularidades como es la presencia de un tipo de estructuras de "muro y caja" (23), en las que hay ofrendas de alfarería altiplánica, lo que denota su uso ceremonial; paralelamente, los extensos cementerios de Chiuchiu y Lasana ${ }^{(24)}$, fueron ocupados por poblaciones de varias fases de la Tradición del Desierto.

El complejo Toconce Mallku representa a las poblaciones de la Tradición altiplánica durante el Período Intermedio Tardío que en la cuenca del Salado, región del Loa Superior, se inicia hacia los 800 d.C. Sus asentamientos ocupan las tierras situadas entre los 3000 y 4000 m.s.n.m., de las subregiones de río Salado y río San Pedro, en el sector septentrional de la Provincia de El Loa y la región de Lípez del altiplano meridional, en el sur de Bolivia. Se conocen más de una veintena de sitios de esta filiación en ambas vertientes de la subárea circumpuneña, siendo el de mayores dimensiones, el sitio de Likan, en Toconce ${ }^{(25)}$. Las formas de ocupación del espacio son muy diferentes a aquellas de las poblaciones de la Tradición del Desierto y sus asentamientos cuentan al menos de tres áreas bien definidas: poblado, Chullpas ${ }^{(26)}$ y área de depósitos de almacenaje de alimentos y/o repositorios funerarios. La configuración del patrón de asentamiento, unido a otros indicadores como alfarería negro sobre ante de la tradición altiplánica, son del todo similares a los asentamientos del territorio Omasuyu del Titikaka. A ello debe agregarse la asociación con extensos y complejos sistemas agrohidráulicos. Los estudios arqueológicos realizados en Toconce, han permitido hipotetizar sobre algunos aspectos ideológicos de estas poblaciones, particularmente sobre el culto a los cerros en épocas prehispánicas ${ }^{(27)}$.

Con respecto a la filiación étnica de los materiales arqueológicos de la fase Toconce y al destino de estas comunidades altiplánicas con posterioridad al arribo de los inkas, debe señalarse que la investigación se encuentra recien en sus comienzos. Hace más de medio siglo, E. Hanson ${ }^{(28)}$ sostuvo que después de una ocupación "atacameña" y con posterioridad a la llegada de D. de Almagro, se habría asentado en la cuenca del Salado una población "no atacameña" venida de Bolivia, la que sería el ancestro de los indígenas quechua o aymara parlantes que residen actualmente en Ayquina, Toconce y Caspana. Su hipótesis es básicamente correcta, por lo menos al identificar un sustrato "atacameño" y una población altiplánica posterior. Pero los predecesores "atacameños" de los cuales habla Hanson (aquellos que fundían cobre en la Vega de Turi y a orillas del río Toconce), seguramente no son los mismos que nosotros consideramos como tales y que adjudicamos a Lasana ${ }^{(29)}$ y los presuntos ancestros "no atacameños" de la población indígena actual, evidentemente son distintos a los que estimamos como sus predecesores llegados del altiplano. El problema está en que la población venida de Bolivia no arribo recíen después de Almagro como sugiere Hanson, sino mucho antes, siendo responsable de los restos arqueológicos que hoy atribuimos a la fase Toconce. Tampoco es seguro que constituya el ancestro de la población indígena moderna, al menos no en un sentido directo, ya que los movimientos de poblaciones producidos durante el Tawantinsuyu y en la época colonial, originan muchas interrogantes al respecto.

L. Núñez ${ }^{(30)}$, en tanto, sugirió que las chullpas de Toconce y demás localidades vecinas constituían una manifestación arqueológica de los Lípez, una población de la región epónima que aparece mencionada en fuentes documentales de los siglos XVI y XVII ${ }^{(31)}$. La inferencia tendría su base en las propias chullpas y en la proximidad de estos restos arqueológicos al territorio en que supuestamente vivieron estos indígenas. Núñez propuso, además, que durante el período Intermedio Tardío los Lípez habrían estado organizados como un "reino altiplánico menor o señorio", analógo hasta cierto punto, a los " reinos" lacustres de más al norte documentados mediante la etnohistoria y la arqueología.

Por nuestra parte, desde 1977, sugeríamos que los ocupantes de Likan podrían corresponder a alguna etnía aymara, sin entrar en mayores especificaciones. Basabamos esta presunción en dos hechos aparentes: primero, que las Chullpas de la Subarea Circumtitikaka fueron vistas por los españoles en uso entre grupos que ahora conocemos genéricamente como aymara ${ }^{(32)}$, de manera que los usuarios de las chullpas de Toconce bien pudieron tener igual filiacion etníca; y segundo, que una parte importante de la población actual de Toconce y 
localidades vecinas, tienen apellidos y practican costumbres identificadas como de origen aymara. Era razonable entonces, que la población antecesora en la cuenca del Salado - portadora, como la actual, de varios elementos culturales altiplánicos - tuviese también ese origen etníco. Sin embargo, el problema dista mucho de ser tan nítido. En la medida en que hemos ido accediendo a la información etnohistórica que hay sobre las vecinas provincias de Nor y Sud Lípez, estamos ahora menos dispuestos a arriesgar afirmaciones tan categóricas ${ }^{(33)}$. Sobre todo, sabiendo que algunas fuentes del siglo XVI hacen referencia no a uno, sino a varios grupos etnícos y a diversas lenguas en esas provincias; por añadidura, se dice que el tronco linguístico de los habitantes del Omasuyu - la supuesta región de origen de la fase Toconce - no era el Aymara o Haque $\mathrm{Aru}^{(34)}$, sino el pukina ${ }^{(35)}$. Desde luego, nunca ha sido fácil visualizar a los complejos arqueológicos en términos de comunidades etnológicamente identificables, pero en este caso, creemos que la dificultad debe cargarse mas a la cuenta de una falta de investigación que al problema mismo. Subsiste un panorama etníco y linguístico muy confuso en la Subárea Circumpuneña y lo más aconsejable para el futuro inmediato es multiplicar las investigaciones en esta dirección ${ }^{(36)}$. En todo caso, los materiales arqueológicos de la región considerados en conjunto, hacen posible asegurar que hubo lazos constantes entre las diversas poblaciones del Loa y de éstas con el altiplano meridional y el noroeste $\operatorname{argentino}^{(37)}$

Por último, para el problema de las relaciones entre el Tawantinsuyu y las sociedades locales, se aprecia que las poblaciones del Período Intermedio Tardío, siguieron siendo predominantes en este territorio y probablemente establecieron diversos niveles de consentimiento con los representantes del Tawantinsuyu( ${ }^{(38)}$; por ahora no hay claridad sobre si hubo movimientos de población en el Área Centro Sur Andina en el Período Tardío (1470 1530), que hubieran llegado a involucrar a los pueblos de EI Loa ${ }^{(39)}$.

\section{- Poblaciones, territorios}

De las poblaciones costeras prehispánicas, nos interesa el segmento comprendido entre Pisagua y Taltal, en medio del cual se encuentra Cobija. Este espacio, conocido como la costa desértica de interfluvio, es un territorio con la apariencia de un desolado desierto, en donde la vida no es posible sino a expensas de las aguadas ${ }^{(40)}$. Hay indicios para postular que durante el período Intermedio Tardío, el sector costero que posee las aguadas del Algarrobal y Las Cañas en Cobija, estuvo habitado. Por otra parte, el lugar Ojo de Agua, entre Mamilla y Cobija, está asociado a senderos probablemente prehispánicos que conectaron el Loa con la costa y la aguada de Mejillones (9 km. al sur del puerto homónimo) y tiene alfarería Dupont, uno de los tipos cerámicos clásicos de las poblaciones del interior durante el Período Intermedio Tardío. En cuanto al sector de Antofagasta y sus aguadas, hay presencia de este tipo de cerámica, como también de otras provenientes de los valles de Arica lo que denota, al menos, esferas de interacción entre poblaciones alteñas con otras de la costa norte. Registros arqueológicos provenientes de ámbitos costeros situados entre Arica y Coquimbo, permiten suponer, asumiendo el riesgo de la generalización, que la población asentada transitoria o permanentemente en la costa de El Loa durante este período, había logrado desarrollar la tecnología para la pesca en mar abierto y, un uso intensivo del lobo de mar, con el cual incluso pudo construir embarcaciones como la balsa, para adentrarse en el mar ${ }^{(41)}$. En el arte rupestre, el tema de los balseros, distribuidos entre Tamentica y El Médano cerca de Taltal, unido a otros indicadores, tiende a configurar una situación de movilidad generada por necesidades de intercambio entre grupos asentados transitoria o permanentemente en diferentes ecozonas tanto en latitud como en altitud ${ }^{(42)}$.

Cuarenta kilómetros al norte de Taltal, se localiza la quebrada del Médano, con pictografías en colores rojos, que reproducen escenas de caza de cetáceos con arpón, desde balsas de cuero de lobos y la caza terrestre de guanaco con arqueros ${ }^{(43)}$. Si como lo sugiere Núñez, las balsas fueron usadas tanto por grupos costeños como del interior y los diseños fueron elaborados por personas que periódicamente volvían a sus cabeceras de origen ${ }^{(44)}$, no sería imposible que ellos mismos transportaran cerámica para su uso o para intercambio. De cualquier modo, las aguadas de esta ecozona, estuvieron ocupadas durante el Período Intermedio Tardío, siendo el punto terminal obligado para acceder a los recursos del mar. Si en la costa han quedado evidencias de estas relaciones, en las tierras altas no sólo el arte rupestre da cuenta de estos nexos. Mostny exhumó sardinas secas en un contexto funerario de Chiuchíu ${ }^{(45)}$ y se han registrado conchas del Pacífico en varios sitios habitacionales y funerarios del Período Intermedio Tardío en la Provincia de El Loa. La carencia de estudios arqueológicos sistemáticos en esta costa desértica de interfluvio, no permiten otro nivel de sugerencias, pero la documentación colonial establece claramente la movilidad de productos desde la costa de Antofagasta hasta Potosí.

\section{- La población indígena de Atacama según los documentos coloniales}

Como en el caso del período prehispánico, los investigadores se encuentran nuevamente frente a un universo fragmentado, contando con documentos que tienen distintas calidades en la información que entregan. Se ha identificado la existencia de una población de Atacamas que tiene como núcleo Atacama la Alta, -hoy la región de oasis del Salar de Atacama- pero que además están presentes en un vasto territorio que incluye ambas vertientes del área circumpuneña. Con el objeto de comprender esta dinámica, Martínez utiliza las nociones de "Poblaciones entretejidas y de territorialidad interdigitada" ${ }^{(46)}$ que dan cuenta justamente de la complejidad de las presencias étnicas en Atacama colonial y en la subárea mencionada. En una aproximación que compartimos, este autor distingue entre etnicidad, identidad y diferenciación. "Es muy posible que en un área determinada una misma etnicidad se exprese a través de diferentes identidades y que, mas aún, sea factible percibir juegos de diferenciación locales entre grupos que pueden o no estar vinculados por identidades o etnicidades comunes" ${ }^{\text {(47). }}$.

A partir del siglo XVI en toda la subárea circumpuneña, un sistema de complementariedad ecológica parece normar todo un conjunto de presencias indígenas entre grupos y territorios vecinos, producto de una larga tradición de relaciones mutuas entre lípes, atacamas, humahuacas, chichas y otras poblaciones cuyas diversas manifestaciones podrían dar cuenta de identidades diferentes, pero no necesariamente de etnicidades $\operatorname{distintas}^{(48)}$.

En este contexto macroregional y en lo particular, en el espacio que ocupó el Corregimiento de Atacama (vertiente occidental circumpuneña), la administración colonial distinguió entre atacamas que sería la población del interior y 
"camanchas" o "camanchacas ", para identificar a la población costera, especialmente la del asentamiento de Cobija, ambas con su propia lengua de acuerdo a la mirada del administrador colonial. No obstante, el panorama que han logrado ir desentrañando los etnohistoriadores especialistas en esta área, es mucho más complejo ${ }^{(49)}$.

- Los habitantes indígenas del puerto de Cobija y costa aledaña.

Desde los inicios de la presencia colonial, diversos autores se refirieron a los habitantes de Cobija como "bárbaros", "gente bruta", "pobres" o "miserables" y luego, denotaron la riqueza de los recursos marinos de esta ensenada. ${ }^{(50)}$ En términos generales, los pescadores que vivían a lo largo de la costa del norte grande de Chile llamaron la atención de los europeos fundamentalmente en tres aspectos: su condición de vida, a la que aluden los epítetos que ya hemos mencionado; su movilidad y el aprovechamiento integral del lobo marino, para la construcción de balsas, viviendas, vestimenta, recipientes, cordelería y alimentos. Estas poblaciones habían logrado una buena adaptacion a este ambiente que incluia el mar, roqueríos, playas e islas y la zona de la Cordillera de la Costa que les proporcionaba otro tipo de recursos, vegetales y animales, como el guanaco. Pudieron disponer de ciertos excedentes - productos del mar secos y/o salados, conchas y guano - susceptibles de intercambiarse con recursos y bienes de tierras altas. ${ }^{(51)}$

Durante el siglo XVI, la población indígena presente en Cobija fue denominada bajo los siguientes términos: Camanchacas, urus, pro - anches y changos. La única referencia de uros en Cobija, está señalada por Pedro Sande en 1581:

En la ensenada de Atacama, ques donde está el puerto, hay cuatrocientos indios pescadores uros, que no son bautizados ni reducidos ni sirven a nadie, aunque a los caciques de Atacama dan pescado en señal de reconocimiento. Es gente muy bruta, no siembran ni cojen y susténtanse de solo pescado. ${ }^{(52)}$

Algunos autores consideran que esta población pudo ser originalmente segmentos de uros del altiplano que se establecieron en el litoral, mientras que otros investigadores, afirman que la denominación "uro" podría haberse originado a causa de su condicion de pescadores, ${ }^{(53)}$ en general pobres y menospreciados, tanto por sus vecinos indígenas como por los europeos y que compartían un modo de vida "bárbaro" con los uros altiplánicos, de acuerdo a las connotaciones con que en ese tiempo se cualifica a los grupos cazadores recolectores. ${ }^{(54)}$

En cuanto al término Camanchaca, una de las primeras menciones parece ser la de Francis Drake en 1578, al referirse a los habitantes de la costa al norte de Copiapó. ${ }^{(55)}$ Mucho más específica es la Información de Juan de Segura en 1591, aludiendo a camanchacas de Cobija. ${ }^{(56)}$ Esta denominación siguió en uso hasta mediados del siglo XVII, ${ }^{(57)}$ para nombrar a población de este lugar.

Quizá si el único relato temprano que intenta caracterizar físicamente a los camanchaca, situándolos en el primer repartimiento de Chile, Copiapó y que de paso, refiere alguna de sus costumbres, es el de Lizárraga, a fines del siglo XVI:

en este trecho de tierra hay algunas caletillas con poca agua salobre, donde se han recogido y huido algunos indios pescadores, pobres y casi desnudos; los vestidos son de pieles de lobos marinos y en muchas partes desta costa beben sangre destos lobos a falta de agua; no alcanzan un grano de maíz y no lo tienen; su comida solo es pescado y marisco. Llaman a estos indios camanchacas, porque los rostros y cueros de sus cuerpos se les han vuelto como una costra colorada, durisimo; dicen les proviene de la sangre que beben de los lobos marinos, y por ese color son conocidísimos. ${ }^{(58)}$

Una reflexión al margen. El comentario de Lizárraga de que en estas caletas se refugian indios pescadores, invita a especular sobre si no se tratará de gente pescadora del lago Titicaca. Una de las tantas interrogantes que queda sin respuesta y que no significa negar la existencia de una población preexistente asentada en la costa por milenios.

Bittmann sugiere que es probable que los pescadores del norte de Chile en la época colonial temprana, hayan comprendido diferentes etnias cuya área de distribución en algunos casos o, por lo menos, en el de los "camanchacas", comprendiera hasta el litoral del sur del Perú. Estas etnias incluirán a camanchacas, pro-anches y changos, ya que ellos aparecen diferenciados en distintas fuentes; "pro-anches" y "camanchacas" registrados en los libros parroquiales de Cobija y la presencia de "camanchacas ", diferenciados sobre la base de un criterio linguístico en Chulín, Perú. ${ }^{(59)}$

Esta misma investigadora consigna un dato aislado y novedoso al mismo tiempo, respecto de los "camanchaca", apelativo dado a ciertos indígenas de la costa meridional del Perú de acuerdo a un documento de la Colección "Egerton 1816" (Museo Británico, Londres, fol.223) que contiene datos acerca de un relato proporcionado al Capitán Francisco de Cadres, por un indio nombrado Chepo, de 115 o 120 años de edad, en el que narra viajes marítimos realizados por los indígenas desde los puertos de Arica e Ylo, respectivamente. Según la declaración de Chepo, llegaron después de dos meses de viaje a una isla desertica llamada Coatu y, posteriormente, a dos islas llamadas, la una Qüen, la otra Acabana. Estas islas eran gobernadas por jefes; allí había llamas y venados y los habitantes vestían ropas de algodón y lana. En dichas islas adoraban a un ídolo de oro al que le hacían ofrendas de este mismo metal, piedras azules, rojas y blancas y finos textiles de lana y algodón de todos los colores. Consultado sobre el idioma de los moradores de estas islas, Chepo contesto que "entendían la lengua de $D$. Sebastian Camanchac". Señalo además, que los indígenas habían realizado dichos viajes en balsas de madera. Aunque tan sólo se refiere a un caso, la nota es de interés, ya que indica que don Sebastian Camanchac - y presumiblemente los demás "camanchacas " que estaban en el sur del Perú eran considerados "forasteros" o, por lo menos, se distinguían como grupo linguístico de los demás indios de aquella parte del litoral. Bittmann no conoce la fecha del documento citado, pero supone - creemos que acertadamente - que dataría del siglo XVI, siglo de documentadas exploraciones de sajones a las costas del Pacífico sur. ${ }^{(60)}$ 
De naturaleza diferente y aunque brevísima, la información que ofrece Santa Cruz Pachakuti es tremendamente significativa, cuando cualifica a los camanchas pescadores de Atacama como "grandes hechiceros". ${ }^{(61)}$ Los ibéricos, no sólo estigmatizaron a los indios cazadores recolectores considerándolos "salvajes", sino también quisieron hacer notar que a ello se sumaba el ser "idólatras".

María Rostworowski ha observado una relación longitudinal entre valles de la costa sur andina, que Galdós ha constatado entre los puertos prehispánicos de Arica, Ite, llo y Chule, a cuya población los cronistas y visitadores llaman "yungas pescadores" y que serían los camanchacas mencionados por Lizárraga, quienes como etnia, figuran en documentación del siglo XVII (1639) en el Archivo Departamental de Arequipa. ${ }^{(62)}$

Es también a mediados del siglo XVII que se utiliza el término de pro- anches para población del sector de la costa aledaña de Morro Moreno y de Caldera, más al sur. Este apelativo sólo aparece en esta centuria e identifica a los pro- anches como originarios de Copiapó y Morro Moreno, aunque inscritos en partidas de bautismo y matrimonio de Cobija. En esta misma época, ${ }^{(63)}$ se empieza a usar la denominación de changos que a partir de 1665 es la única que permanece vigente hasta el siglo XIX, para identificar a las poblaciones de Cobija y de Copiapó. ${ }^{(64)}$ Para Bittmann "Changos" o "chiangos" también es un nombre utilizado para designar desde por lo menos mediados del siglo XVII, a grupos de pescadores recolectores y cazadores costeros, habitantes de la franja del Pacífico entre aproximadamente los $17^{\circ}$ Lat. S. (sur del Perú) y los $30^{\circ}$ Lat. S. (Tongoy en la costa chilena). ${ }^{\left({ }^{65}\right)}$ Casassas especula que el término pro-anche es una deformación del vocablo quechua purum -auca o poro - auca y que podría haberse aplicado a camanchacas no sometidos; la argumentación es débil aunque sugerente. ${ }^{(66)}$

En el Libro de Varias Ojas de la Parroquia de Chiu - Chiu, aparecen nombres propios de los proanches, que no se repiten para otras poblaciones y que desaparecen de los registros parroquiales a partir del siglo XVIII. Según Bittman los apelativos Alaguana Jaguaña, Chacaguaina, Anchuño; Calpiche (Chalpiche), Cancota, Coimas, Cherepe, Chamalco, Chiquin,Lacmor, Laicor, Maqueta, Quilama, Sacaya (Sajaya, Sacalla), son nombres que con la excepción de "Cacaia" y "Jaguaña", eran propios de la población del litoral designada "proanche " en el sentido de que estos nominativos no aparecen en las inscripciones referentes a personas del interior de la región atacameña, ni se encuentran asociados a los demás pobladores de la costa. ${ }^{(67)}$

Se señalan además matrimonios entre pro - anches y camanchacas, lo que al menos, implica su coexistencia y diferenciación. La mayoría de las menciones a pro -anches en el LVO, se centran entre los años 1646 y 1662 y generalmente se denota que proceden de la jurisdicción de Chile y más específicamente de Morro Moreno y Copiapó ${ }^{(68)}$

Ahora estamos en condiciones de preguntarnos a que pueden aludir estas denominaciones. En una primera aproximación, uno podría pensar que se trata de grupos etnícos distintos; no obstante, la complejidad que encierran alguno de estos vocablos - como el de uro por ejemplo- y la poca precisión de las fuentes obligan a una saludable cautela. Estamos frente a conceptos que pueden comprender actividades diferentes, procedencias $u$ origenes, niveles sociales, entre otras posibilidades. En este sentido es sugerente la observación de Bibar en 1558 que señala que;

los que matan lobos no matan otros peces como habemos dicho y los que matan toninas es en ejercicio. Así que cada género de pescador mata el género de pescado a que se aficiona y no otro. ${ }^{(69)}$

Aunque la observación es general para la costa comprendida entre Arica y Coquimbo, sabemos que las denominaciones de camanchacas y changos, fueron usadas con la misma extensión. Por otra parte, el término uro, tiene una serie de connotaciones, entre otras, de personas que no se dedican a la agricultura, sino más bien a la recolección, la pesca, la caza y eventualmente el pastoreo y por añadidura son percibidos como "pobres". ${ }^{(70)}$ Bien podría tratarse, de que estas denominaciones no designen etnías distintas, sino grupos con actividades económicas especializadas y de otro lado, similares, como en este caso las propias de una económia marítima. ${ }^{(71)}$ John Murra señaló hace casi 40 años, que se necesitaba más investigación para determinar hasta que punto "uru", se refería a un grupo etníco o a un estrato ocupacional bajo o mas probablemente a ambos. ${ }^{(72)} \mathrm{A}$ pesar de las nuevas investigaciones sobre este grupo, ${ }^{(73)}$ todavía el problema no esta resuelto. Hacemos notar que prácticamente en todas las descripciones sobre los uru, esta siempre presente la idea de lo no domesticado en toda su extensión.

Según Espinoza Soriano ${ }^{(74)}$, la documentación del siglo XVI y primera parte del XVII, demostraría que la lengua puquina se extendía por el altiplano peruano-boliviano, más al sur del departamento del Cuzco, Arequipa, Moquegua y el Norte de Tarapacá incluyendo a Atacama. La tesis de que la lengua de los uros era el puquina(75) es una proposición bien documentada, pero aún parcial. ${ }^{(76)}$

En cuanto a la lengua o las lenguas que se hablaban en Cobija, ${ }^{(77)}$ documentos del siglo XVII son claros en denotar que "hablan diferente lengua y tan rudas que no ai, quien los entienda, si bien hablan la española"(78). A mediados de este siglo, relatando su experiencia evangelizadora, el cura de Atacama, escribe que desarrolla sus prédicas en Cobija "en la lengua materna de los indios camanchacas" a quienes alude como.

"Ios del mar que son camanchacas Pescadores y de diferente nación que estos atacamas" (...)enseñando e industriando a los indios de este su beneficio de atacama la baja y camanchas y chiangos avitadores en estos puertos de mar por auer mas de ueinte y un años que aqui les administra Los santos sacramentos y travajar con ellos enseñandoles en estos dichos Puertos como son cubija colupo yquique y loa y demás partes enseñandoles la dotrina Xptiana en que estan los dichos indios muy bien industriados $y$ catequisados $(\ldots)^{(79)}$ 
Desde luego, el párrafo es muy sugerente. No sólo usa el término camanchacas sino también changos, distingo que también es claro en otro documento de la época. En lo que concierne al área de distribución de los changos, existe una referencia a los "indios camanchacas y chiangos, pescadores y no pescadores, que de mi encomienda estuvieron en Cobija y costa de Atacama...". Dichos indígenas habían huido de su encomendero de acuerdo a un documento otorgado en la ciudad de La Serena en 1659 y que se refiere a la encomienda de Fernando de Aguirre Riberos. ${ }^{(80)}$ Pero, en opinión de María Rostworowski, el nombre camanchacas, prácticamente es sinónimo de pescadores y recurre a Cuneo Vidal que señala que camanchaco, camanchango o chango eran voces para designar a los mismos grupos de pescadores; la palabra chango habría derivado de las primeras, ${ }^{(81)}$, aseveración esta última que nos parece acertada y que podemos refrendar, teniendo en consideración el documento que hemos citado en líneas precedentes.

Concordando con Murra, ${ }^{(82)}$ Martínez sugiere la posibilidad de que los conceptos con los que se identifican a los grupos costeros podrían estar encubriendo categoréas sociales, religiosas o especializaciones productivas y no necesariamente identidades etnícas distintas. ${ }^{(83)}$

Otro problema que no escapa a los investigadores y que está presente a partir de los documentos del siglo XVI, es la aparente relación de subordinación que tienen los pescadores frente a los señores de Atacama y que ya Pedro Sande notara cuando relataba que los indios "pescadores uros "(...) á los caciques de Atacama dan pescado en señal de reconocimiento". ${ }^{(84)}$ En este contexto recordemos que Polo de Ondegardo en 1571, señalaba las dificultades que surgían en el Collao, al tratar de encomendar los indios de los valles costeros, porque pertenecía a cabeceras que estaban en la altiplanicie. ${ }^{\left({ }^{85}\right)}$

Sin duda que la problemática reseñada respecto de los grupos indígenas asentados en la costa, nos deja muchas más preguntas que respuestas. Hablar aquí de una identidad cultural sólo nos puede remitir por el momento, a la configuración común del compartir prácticas en torno a ciertas actividades económicas relacionadas fundamentalmente con los recursos marinos y a retazos de una historia precolombina aún no bien delineada, con el agravante que de esa población indígena practicamente no quedaba nadie a fines del siglo XIX y que los pescadores de antaño, en su mayoría, se dedicaban a la minería en esa misma época. ${ }^{(86)}$

La gente que a principios del siglo $\mathrm{XX}$ es reconocida como chango, pertenece a un conjunto de familias de pescadores que habitan el litoral chileno, en asentamientos precarios y transitorios, de acuerdo a la percepcion de Latcham, quien relata que construyen sus casas con lo que encuentran en las caletas:

Aun hoi en día, en los lugares mas apartadas, hacen la misma cosa, usando ademas cuando los pueden conseguir, hojas de lata secadas de los tarros parafineros; sacos viejos, lonas, etc. Cuando la vecindad de algún puerto lo permite, a veces procuran algunas planchas de fierro galvanizado, o tablas, por la mayor parte sacadas de los cajones usados para la trasportación de mercaderías.

El ajuar de estos ranchitos es de lo mas escaso i primitivo. Duermen en cueros tendidos en el suelo, no usan almohadas, o cuando más un trozo de madera.

Sus ollas son de barro, de fabricación tosca, pero de varias formas. Una concha de mejillón les sirve de cuchara, $i$ a veces tambien de cuchillo. Unos sacos de cuero, colgados de los postes de los ranchos sirven para guardar su comida. ${ }^{(87)}$

\section{- Los habitantes indígenas del interior de Atacama}

La categoría de atacameño, cubre con un manto de homogeneidad a los indígenas de Atacama La Alta y La Baja a partir del siglo XVI. Los papeles coloniales identificaron bajo ese nombre, a toda la población que habitaba el territorio delimitado por la administración española como Atacama, señalando que hablaban una lengua "por sí", ${ }^{(88)}$ hoy prácticamente desaparecida.

Ese es el panorama general. Sin embargo, el laborioso trabajo de Casassas, unido a las finas investigaciones de Hidalgo y Martínez relevando documentación inédita, han logrado ir configurando la dinámica de las poblaciones circumpuneñas que obviamente exceden el marco de Atacama. Es a través de estos estudios que se logra percibir la inmensa complejidad de la trama étnica y al mismo tiempo vislumbrar algo del juego de las identidades en la región.

Lo que ha quedado suficientemente claro, es que la población de la subárea circumpuneña- aparentemente un área de baja densidad demográfica-, se caracteriza por tener actividades económicas regidas por un sistema de complementariedad ecológica que promueve una alta movilidad dentro de un espacio macroregional, ${ }^{\left({ }^{(9)}\right.}$ que en épocas coloniales correspondía al menos a los corregimientos de Lípez, Chichas, Tucuman y Atacama. Se trata de unidades relativamente pequeñas, pero cuya noción de extensión territorial es amplia. Como posibles "núcleos de origen", los Lípez ocupaban preferentemente el altiplano que se extiende desde los bordes del Salar de Uyuni hacia el sur; los chichas, se asentaban en territorios puneños al este de los Lípez en valles intermedios y alcanzando hasta las tierras bajas de la precordillera de Tarija. Los omaguacas, en la quebrada del mismo nombre, estaban distribuidos en distintas parcialidades, rodeados por grupos chichas, además de casabindos $y$ cochinocas, que en la información colonial, suelen ser nombrados juntos y que habitaban sectores de la puna aledaña a Huamahuaca. ${ }^{(90)}$

Las primeras noticias del siglo XVI, ya muestran una fuerte interrelación entre los atacameños del Salar y los chichas, un vínculo que la arqueología también ha podido comprobar para épocas prehispánicas. ${ }^{(91)}$ Es muy impresionante constatar el poder de esta especie de reciprocidad política en el proceso inicial de defensa desarrollada por los indígenas y en su posterior pacificación. Como ejemplo, en el primer caso, encontramos a un curaca de Atacama - Viltipoco - dirigiendo la resistencia de "humahuacas, casabindos, calchaquíes y otros", ${ }^{(92)}$ en territorio jujeño contra los españoles. En el segundo caso, la pacificación de los Atacamas en 1557, a cargo de Juan Velásquez Altamirano, parece haberse logrado únicamente por la intermediación del curaca de Chichas y sus indios. Las ceremonias iniciales de la Pacificación se realizaron no en Atacama, sino en sur Chichas: 
La gestión del mallku de los chichas prosiguió con la invitación a don Juan Cotocotar, dirigente principal de los Atacamas y a muchos de sus indios y principales a la localidad de Suipacha. ${ }^{(93)}$

Estos ejemplos, no hacen sino denotar que estas reciprocidades están vinculadas a segmentos de una compleja relación política y social en la cual hay comprometidos varios grupos de los que no percibimos sus identidades, pero que están entramados unos con otros. Hay, entre ellos, posibilidades de arreglos dinámicos de acuerdo a las situaciones que enfrentan, que los hacen producir configuraciones comunes, gestos compartidos que pueden conformar una identidad y al mismo tiempo mantener sus diferencias. ${ }^{(94)}$ Pero también estas últimas, pueden ser producto de la percepción española, más que de la realidad indígena de ese momento.

¿Cómo entender la relación de Lozano de Machuca cuando escribe en 1581, que hay indígenas" que confinan con los indios de guerra de Omaquacas y Casavindo" y que "entran en Potosí con nombres de indios lípes y atacamas"?, ¿Porqué ellos pueden adoptar un nombre que pareciera no ser el propio, o mejor dicho, ¿Qué significa según el contexto cada uno de estos nombres?. ${ }^{(95)}$

Podemos reflexionar sobre varias posibilidades no excluyentes al pensar estas denominaciones, pero aún no podemos hilar tan fino como para optar por una u otra. T. Platt por ejemplo, sugiere que la denominación de lípes, "no remitiría a un grupo específico, sino a todos aquellos que practicaban la caza de la vicuña con la técnica del lipi". ${ }^{(96)}$ Fernandez por otra parte, piensa que el término "los lipes", en la Carta del Factor de Potosí, puede significar, más bien, un repartimiento, una provincia o un territorio, antes que un conglomerado étnico definido. ${ }^{(97)}$

Cabría preguntarse entonces, hasta donde tienen sentido las "unidades" que resultan de la lectura de la documentación del siglo XVI o ¿Cuándo la identificación de una "nación", indicadas en la documentación se corresponde realmente con una identidad étnica previa y funcionante? ${ }^{(98)}$

La información con que se cuenta para el siglo XVII, es mucho más abundante y ha permitido a los etnohistoriadores $^{(99)}$ distinguir la red de relaciones que se dan en forma diferente en Atacama La Alta y Atacama La Baja. Esta distinción, ya percibida para tiempos prehispánicos perdura hasta hoy, con diferentes énfasis, matices e intensidades, a pesar del transcurrir de los siglos y de todos los cambios ocurridos.

La situación en Atacama La Alta muestra que, prácticamente, a través de toda su historia, las poblaciones del Salar, las del Noroeste argentino y de Lípez han estado interdigitadas, a través de una dinámica que marca con mayor énfasis la presencia de atacameños allende la cordillera. Este proceso de movilidad perdura con mucha fuerza hasta fines del siglo XVIII, una gran época de crisis para el mundo indígena ${ }^{(100)}$, pero reiteramos, con todas sus modificaciones en el tiempo, es posible percibirlo hasta hoy. Los análisis de Hidalgo y Martínez, han demostrado que en el siglo XVII los ausentes por largo tiempo, representaban cerca del $60 \%$ de la población, en tanto que los caravaneros o los que "van y vienen", no serían más del $7 \% .{ }^{(101)}$ Una característica común a estos desplazamientos es que los indígenas, aunque permanecieran mucho tiempo ausentes, no perdían sus derechos y deberes en su núcleo de origen y por tanto en el lugar en donde se encontraran, pagaban la tasa al cacique de su pueblo. Su curaca, siempre sabe donde se encuentran y conoce en detalle su situación, aunque estén residiendo en otro lugar por más de 20 años. ${ }^{(102)}$ Los lugares más frecuentados por los indígenas de los ayllus del Salar de Atacama son, por ejemplo, los alrededores del río San Juan en Tucumán, lugar en donde llegaron a vivir más de setenta atacameños, dándose el caso de tener un mayor número de población originaria del Salar, que el propio supuesto lugar de origen. Incluso en el siglo XVII, la localidad llegó a llamarse "río San Juan de los Atacamas", ${ }^{(103)}$ probablemente por la ocupación reincidente de gente del salar de Atacama en ese lugar. También se los encuentra residiendo en Lípez, Salta y Catamarca. ${ }^{(104)}$ Otro aspecto recurrente de esta movilidad, es que la población de cada ayllo de San Pedro de Atacama tiene lugares específicos que frecuenta y no otros; por ejemplo, los miembros del ayllo de Solor parecen no haber ocupado espacios en Tucumán ${ }^{(105)}$ y los de Sequitur, no registran una presencia en territorio chicha. ${ }^{(106)}$

El territorio de Atacama la Alta, acusa poca frecuencia de foráneos en relación a Atacama La Baja. ${ }^{(107)}$ En esta última doctrina, como norma, hay una fuerte presencia de forasteros, especialmente de Lipez, durante los siglos XVII y XVIII. ${ }^{(108)}$ Lipez y Picas coinciden en Chiu Chiu y Calama, lugares inevitables en el tráfico entre la costa de Cobija y el altiplano. En las tierras altas del río Loa, aunque ambos grupos buscan espacios con buen forraje para actividades ganaderas, ocupan diferentes lugares. En los registros eclesiásticos del XVII, los lipes aparecen asentándose en lugares como Aiquina, Caspana, Toconce e Inacaliri situados todos sobre los 3000 metros de altitud en las subregiones de río Salado y río San Pedro afluentes del Loa, ${ }^{(109)}$ Díaz de Guzman llega a decir incluso que Atacama es "tierra de Olipes" ${ }^{\prime 110)}$, en cambio los de la doctrina de Pica, ocupaban las estancias ganaderas ubicadas en los bordes del río Loa, ${ }^{(111)}$ posiblemente en aquel sector del Loa Superior en donde el plano inclinado asciende paulatinamente desde la actual localidad de Conchi, pasa por Lequena y alcanza las nacientes del río Loa a los pies del volcán Miño(112)

Además de esta movilidad a larga distancia, la gente de ambas Atacamas se mueve a distancias de 1 a 4 días de camino dentro de su territorio, viviendo por largos períodos en esos lugares o transitando por temporadas, tal como acontece hoy día. Hubo contactos frecuentes entre ambas Atacamas, sea a nivel de unidades domésticas y de sus actividades económicas, sea en razón de situaciones coyunturales que debieron afrontar conjuntamente, como las fases de la rebelión indígena del siglo XVIII lideradas en la región por el aiquineño Tomás Paniri. ${ }^{(113)}$

Enunciada esta normada y compleja trama de relaciones tejida por diferentes grupos, no nos queda más que preguntarnos cuántas identidades o grupos étnicos están presentes en la subárea circumpuneña, comunicándose permanentemente y poniendo en juego lazos de parentesco a través del matrimonio y compadrazgo, como una táctica de las unidades domésticas para acceder a logros económicos y sociales. ${ }^{(114)}$ Es por esta razón que en el territorio de Atacama, aquellos grupos conocidos tradicionalmente como Atacamas y Lipez no siempre pueden pensarse separadamente, lo que no significa borrar las diferencias. 
Bosquejada la población indígena y su movilidad territorial, durante los períodos prehispánico y colonial, en las páginas siguientes, ofreceremos una mirada en el presente, sobre algunas de las poblaciones mencionadas.

\section{- Continuidades y transformaciones}

La investigación contemporánea, ha documentado ampliamente el proceso de evangelización emprendido por la colonia española en toda Ámerica, como una de sus principales empresas. La región de estudio, no estuvo ajena a este proceso; es más, al menos en Atacama La Baja, durante el siglo XVII, se llevó a cabo un fuerte proceso de extirpación de idolatrias ${ }^{(115)}$. Parece que este fenómeno reforzó la necesidad de una evangelización dentro de pequeños grupos de población, la que no obstante, pudo resistir, bajo la modalidad de una religión yuxtapuesta, ${ }^{(116)}$ adoptando y adaptando elementos de la cristiandad, junto a sus propias formas de vivir su religión y sus costumbres.

Etnográficamente, podemos seguir distinguiendo estos dos núcleos de población indígena, aquellos de la región del Salar de Atacama y los que se organizan en la subregión de río Salado. Para este período, no vamos a desarrollar una síntesis de las investigaciones sobre el tema; trataremos de visualizar el problema de las identidades, recurriendo a algunos ejemplos.

Varios de los pueblos de la Provincia de El Loa tiene una existencia que puede documentarse desde la colonia, en tanto que otros, son el resultado de procesos de subdivisión de un pueblo en época colonial o republicana. Unos y otros se han visto enfrentados al proceso de occidentalización desde el siglo XVI y con mucha fuerza, al proceso de chilenización por el Estado nacional. No obstante, en este largo proceso han logrado ir re- creando sus identidades de un modo más, o menos exitoso, para seguir reconociéndose diferentes entre ellos y frente al Estado.

Para esta mirada, consideramos útil referirnos a algunas de las características más recurrentes de estas comunidades, que de algún modo nos hacen reconocerlas en el presente etnográfico.

Desde el punto de vista económico, la actividad tradicional es agroganadera y de recolección, normada bajo un mecanismo de complementariedad que incluye macro y micro distancias. Ello genera un patrón de asentamiento con un núcleo central - el pueblo - y un asentamiento disperso en estancias que pueden ser de ocupación más, o menos permanente. Estas actividades se desarrollan de acuerdo a pautas tecnológicas ancestrales ${ }^{(117)}$ y se combinan con trabajos de artesanía como textiles y producción cerámica ${ }^{(118)}$. Junto a esta economía tradicional, desde la colonia, estas comunidades han incorporado prácticas asociadas a la economía mercantil. Primero fue, por ejemplo, el tráfico de pescado de Cobija a Potosí o trabajos esporádicos en la minería; a partir del siglo XVII, la arriería $^{(119)}$ fue una actividad esencial y a comienzos de este siglo una de las inserciones más frecuentes ha sido en la minería. A través del tiempo, la plata de Caracoles, el auge del salitre, el trabajo en las azufreras, las obras del ferrocarril y las aducciones de agua han sido espacios ocupados laboralmente por los pobladores de El Loa, con el objeto de obtener el circulante necesario para subsistir. Este sistema económico está permanentemente en tensión, sea por la falta de agua para las actividades tradicionales, sea por la escasez de trabajos remunerados, pero de una $u$ otra manera, por innumerables mecanismos, los lugareños han logrado arreglos que les permiten seguir existiendo vinculados a sus lugares de origen, no obstante que la mayoría de las familias, poseen casas en Calama, fundamentalmente para poder acceder a la educación formal para sus hijos.

En el plano social, cada pueblo tiene una Asamblea Comunal constituida por el conjunto de comuneros que son los que poseen tierras cultivables en el lugar; estas pueden obtenerse por nacimiento, matrimonio o por petición a la Asamblea comunal, que dirime democráticamente cualquier asunto de interés común. Con mucha flexibilidad, han logrado mantener sus propias autoridades que los representa tanto frente al Estado, como entre comunidades ${ }^{(120)}$. Un elemento muy propio de estos pueblos son un conjunto de jerarquías indígenas - los cargos que están estrechamente vinculados a sus costumbres originarias como a su particular religiosidad. Las costumbres, en su propio concepto, son aquellas prácticas ceremoniales y rituales que viene de los "abuelos", de los "antepasados", de los "antiguos". A estas costumbres, deben agregarse las formas particulares en que ellos practican la cristiandad. No es extraño que a nivel ritual, aspectos cristianos y costumbres ancestrales formen una sola red, pero a nivel de pensamiento, priman las concepciones no occidentales. Estas son explícitas en su oralidad y en la praxis cotidiana. ${ }^{(121)}$

La población indígena es poseedora de una ciencia que categoriza y ordena los espacio naturales y sus recursos $^{(122)}$. Pero a diferencia de la ciencia occidental, esta ciencia indígena se subsume al mismo tiempo en una filosofía, en un saber que integra los distintos niveles de la vida cotidiana, una forma de percibir el mundo que incluye inseparablemente, aspectos económicos, sociales y religiosos ${ }^{(123)}$. El coparticipar de esta tradición que incluye todas las esferas de la realidad, marca una de las diferencias fundamentales con la sociedad mayor.

Estos valores compartidos se perciben nítidamente en sus ceremonias. Sin duda, muchas de ellas tiene un origen prehispánico y no son privativas de los indígenas de El Loa. Son parte de lo que genéricamente llamamos el mundo andino. La particularidad estaría dada por los diferentes matices que le otorga cada comunidad, aspecto que puede observarse por ejemplo en la limpia de acequias o canales ${ }^{(124)}$, la que cuenta con especialistas llamados cantales en Socaire y Puricamani en la subregión de río Salado y de otra serie de cargos que deben conducir a buen término la celebración para el agua. Se trata de una compleja ceremonia que dura seis días y en la cual participan los comuneros - como unidad doméstica -, visitas y forasteros. Al menos en la subregión de río Salado, cada comunidad recibe las visitas de otras comunidades. En el transcurrir de las diferentes fases de esta ceremonia - como prácticamente en todas las costumbres- se invoca a los "abuelos", a los cerros tutelares o mallku y a la Pachamama o "santa tierra Pachamama". Hay en ellas, una carga simbólica muy fuerte que se denota en los gestos del "chuspanear"- el acto recíproco e invitado de coquear intercambiando las chuspas -, en la música, en la danza y en el conjunto de especialistas, principales y familias de comuneros que participan en las ofrendas. Todo ello remite a un pasado prehispánico activo en el presente y que va dirigido a pedir por la abundancia del agua. La estructura es básicamente la misma en los pueblos de El Loa, con diferencias locales que pueden apuntar a reafirmar microidentidades o a marcar las diferencias, por parte de los mismos actores, 
entre un pueblo y otro. Por ejemplo, en Aiquina se reza un cántico cristiano " El Alabado" en la merienda almuerzo y cena comunal- y se dice que no se canta en quechua para los bailes denotando que si lo hacen en Toconce ( $y$ es asi). En Toconce, en lugar del Alabado se prefiere hacer una liturgia y se canta en quechua y castellano para los bailes. Los bailes son los mismos porque son los propios de la limpia de canales en estas dos comunidades: "la ventana" y el " pa'tras, pa' delante". En el Salar, al menos en Socaire, los cantales hacen su invocación a los cerros en lengua kunza ${ }^{(125)}$

Justamente es en estas ocasiones de reuniones colectivas, cuando los pobladores marcan las diferencias. Por ejemplo, en el transcurrir de las ramadas de la limpia de canales en Aiquina en Septiembre de 1990, sus comuneros repetían reiteradamente "no estamos ni ahí con el kunza", aquí, "puro castellano no más". "No somos atacameños, somos aiquineños". " Los de Toconce cantan en quechua, nosotros , no". Y la gente de Toconce, de visita en Aiquina, insistían en no ser atacameños, sino toconcinos, diciendo: "los de San Pedro son los atacameños y a todos nos quieren decir igual". Esta aclaración manifiesta hay que apreciarla en su contexto; en esos momentos y ahora, prácticamente es una obligación apelar al nombre de "atacameños" para toda la gente indígena de la Provincia de EI Loa; de otro modo no es posible ser representados y reconocidos por la Conadi; aiquineños y toconceños tenían claro que de otro modo no podían acceder a los beneficios de este organismo, pero se encargaban de dejar en claro las diferencias. Sin duda una identidad necesaria para ser reconocidos por una entidad gubernamental, con los mismos derechos que los aymara de la primera región, los mapuche y los pascuenses.

Existen otras ceremonias que practican todos estos pueblos y en las que siempre se reafirman sus identidades en forma persistente. Aprovechando un análogo hispano - Todos Santos- también se recuerda a los muertos según antiguas costumbres $^{(126)}$. En esta ceremonia tiene un rol sustancial el yatiri - especialista religioso que sabe las costumbres-, junto a los principales de cada pueblo y los rezadores, que son personas que han escrito libretas con oraciones católicas, tienen su propio estilo y forman cuadrillas que van de casa en casa y al cementerio. En la conmemoración, actúan juntas las prácticas indígenas prehispánicas y los elementos de la cristiandad. Como en la limpia de canales, cada movimiento y cada palabra dentro del ritual, esta normado. En Toconce, funciona especialmente para esta ocasión, la división entre arribeños y abajeños del pueblo, circulando la gente por mitades, de acuerdo a una estricta estructura dual; sólo el último día, para concluir la ceremonia, las mitades confluyen; en cambio en Aiquina, la comunidad funciona como un todo, sin ninguna alusión a mitades. Es significativo constatar que la estructura dual no está siempre explícita, sino sólo en determinadas ocasiones.

Cada una de estas ceremonias y otras, tiene necesariamente diversas clases de waki - ofrendas, mesas y quemas rituales - . En ellas, la comunidad participa como colectivo para lograr sus objetivos: la reproducción, la salud, la abundancia y en definitiva, el bienestar del pueblo. Toda ceremonia requiere de una inmensa cantidad de trabajo por parte de las unidades domésticas, especialmente en la provisión de comida y bebida, para desarrollar con éxito la conmemoración y para activar los lazos de reciprocidad internos y con las otras comunidades. El mismo trabajo demandan las celebraciones de los elementos incorporados de la cristiandad, en especial, los santos patronos que son celebrados durante varios días. En algunos casos, es muy manifiesto el vínculo entre una comunidad y otra a través de sus santos. Guadalupe de Aiquina visita ("sube") Toconce para la celebración de San Santiago y, recíprocamente, San Santiago, visita ("baja") Aiquina para la fiesta de la Guadalupe. Hay santos sin embargo, que tiene una dimensión más regional y son celebrados especialmente por algunas comunidades. Es el caso de San Antonio "llamero", ${ }^{(127)}$ conmemorado en Conchi y en Toconce y de Santa Cecilia, la patrona de los músicos, celebrada por caspaneños y toconceños, aún cuando, prácticamente, todos los pueblos tiene sus bandas de bronces o de sicus.

Como estas, hay una cantidad de costumbres cotidianas y de su propia religiosidad normada por el ciclo anual que sería imposible ejemplificar aquí. ${ }^{(128)}$ De cualquier forma, existe una estructura común sobre la que se organizan las diferencias y matices y que sólo un trabajo de detalle para cada pueblo y luego comparativo, podría explicitar claramente. Lo que queríamos resaltar, es esta configuración común que les otorga una identidad o los hace diferentes de otros grupos. No obstante, ésta es una de las identidades, la más gruesa, la que podríamos llamar andina, que es un amplísimo concepto; pero como ellos mismos se encargan de hacer notar, hay otras; una para su conexión con el Estado, la de "atacameños" y otra al interior de cada comunidad. ${ }^{(29)}$ Por ejemplo, actualmente los sanpedrinos, mucho más mestizados que el resto de los pobladores de El Loa, y más urbanos en su idea de progreso, llaman coyas a los comuneros de Talabre y Machuca que han tenido que establecerse en San Pedro por el período escolar, para que sus hijos asistan a la escuela. Viven en barrios aparte y son claramente disgregados:

Ya la Punta de Diamante (la población) está lleno de coyas de Talabre, Río Grande; ellos se vienen pa' San Pedro y los de San Pedro se van pa' Calama. ${ }^{(130)}$

No me interesa mucho la ley indígena, pero espero que sí nos ayude a los verdaderos atacameños... los que no somos ni coyas ni afuerinos. ${ }^{(131)}$

Por cierto, el proceso de cambios que sufre San Pedro de Atacama es mas una excepción que un común denominador para los pueblos de El Loa, pero esta diferenciación también puede apreciarse en la región del Loa superior, tanto en términos positivos como negativos. Junto a esta percepción y frente a la crisis, hay múltiples arreglos creativos que surgen en el seno de las propias comunidades y que tocan al problema de las identidades, demostrando su dinamismo y flexibilidad. Ejemplificaremos este proceso sintéticamente en la subregión de río Salado y oasis de Chiu- Chiu.

Chiuchiu, que en el pasado colonial fue asiento de la doctrina de Atacama La Baja y un lugar de tránsito entre la costa y las tierras altas, conservaba hasta la década de los 70 , una población originaria residente en el lugar, que paulatinamente se desplazó hacia Calama, quedando muy pocas familias que conservaron sus tierras. Progresivamente, el pueblo fue recibiendo distintos aportes de población. En la década de los 80, llegaron grupos de la precordillera de la I región, especialmente de Cariquima, que se instalaron en los bordes del pueblo, arrrendaron tierras para cultivar y realizaron sus costumbres separados del resto de la población. Mientras tanto y hasta el presente, comuneros de Caspana, Toconce y Cupo al menos, fueron adquiriendo por distintas vías 
tierras en Chiuchiu, sin abandonar sus pueblos de origen, sino ampliando sus posibilidades de subsistencia. De la misma manera, Lasana a $8 \mathrm{kms}$ de Chiuchiu, de ser una localidad de estancias, ha ido poblándose y conformando una comunidad, con gentes procedentes de las tierras altas del Loa, en donde la crisis por la falta de agua para los bofedales fue haciéndose cada vez más dramática. ${ }^{(132)}$

Las comunidades de Aiquina y Caspana tiene una existencia como pueblo documentada a partir del siglo XVII. Desde ese tiempo, han demostrado una capacidad para seguir existiendo no exenta de crisis, pero que hasta ahora han afrontado con éxito, manteniendo entre ambas lazos de reciprocidad y de competencia como es propio en las sociedades andinas. Incluso, en algún momento de su historia en el siglo XVII, Aiquina y Caspana probablemente tuvieron al menos una autoridad compartida, ${ }^{(133)}$ lo que pudo significar desde una situación de patrón dual con una identidad generada a partir de viejas estructuras, una situación coyuntural surgida durante la colonia o encubrir otra posibilidad no conocida. Sin embargo, los habitantes de Caspana son percibidos como diferentes por las gentes de Aiquina y Toconce. Los aiquineños sostiene que los caspaneños "descienden de los gentiles" - los antepasados prehispánicos más remotos y no bautizados. ${ }^{(134)}$ De hecho para el observador foráneo, a pesar de los muchos elementos de identidad, los caspaneños se acercan más en algunos aspectos a las gentes del Salar; por ejemplo, ellos interactúan bastante con los pobladores de Machuca y Río Grande y también a principios de siglo acudian a asentamientos en el Noroeste argentino. ${ }^{(135)}$ Es curioso que teniendo a uno de los centros productores de cerámica a pocas horas a pie - Toconce-, prefieran, sin embargo, comprar estos objetos en Río Grande; además, para la limpia de canales, aún recuerdan fragmentos de las invocaciones en lengua kunza y el baile principal se llama Chauchau, que imitaría el sonido del agua. ${ }^{(136)}$

Toconce, fue durante el siglo XVII, una localidad de estancias. Recién a principios de este siglo se constituyó como pueblo, con aportes poblacionales de Aiquina, de las estancias alto andinas de Línzor, Inacaliri y otras y de gentes de varias localidades de Lípez, como Colcha y Alota. ${ }^{(137)}$ Incluso hay al menos dos pobladores de Toconce que tiene abuelos originarios de Cochabamba. Aiquina y Toconce tuvieron por largo tiempo una misma autoridad indígena por turno, un año su Alcalde era originario de Aiquina, al año siguiente lo era de Toconce y siempre han mantenido estrechos vínculos de toda índole. Aún así, los aiquineños fluctúan en su idea de identidad con la gente de Toconce y de Cupo; a veces se refieren a que "son todo uno" y diferentes de Caspana y al mismo tiempo, llaman a los toconceños como "vicuñas", "guanacos", ${ }^{138)}$ reconociendo sin embargo, que es un pueblo de excelentes canteros y "productor de buenos yatiris". (los yatiri de Caspana son vistos con cierto recelo.) En el presente y fundamentalmente por la baja densidad de población que reside de manera estable en cada uno de los pueblos, están pensando volver a ser una sola comunidad.

En el ámbito macroregional, las comunidades del Loa superior siguen relacionándose con poblaciones bolivianas sea para intercambios económicos, para contratar a un maestro de música que entrene a la banda del pueblo, sea para contar con un "médico de los yungas" cuando el yatiri local no puede solucionar algún problema y un sinnúmero de otras situaciones que encubren distintos grados de intimidad. Si gente de Lípez, es capaz de entregar a su hijo a una familia del Loa para que lo adiestre en las prácticas del pastoreo por un período de un año o más, habrá que preguntarse acerca de la profundidad y solidez de estos vínculos a nivel de las unidades domésticas.

Sin duda que los pueblos de la Provincia de El Loa poseen un código común de configuraciones que los identifica en lo general con el mundo andino, no necesariamente aymara, no siempre atacameño. Pero también es cierto que cada uno tiene su propia historia particular que los hace diferentes y que juega un rol fundamental a la hora de plantear sus demandas. De ahí la necesidad de escuchar en cada caso, las soluciones a sus problemas propugnadas por los actores y de respetar las diferencias.

En el momento actual, estas poblaciones están viviendo y se ven enfrentadas a dos racionalidades diferentes, la una del Estado y la otra, tradicional. Hasta ahora, las han ido conjugando a su modo y posiblemente esa es la vía más positiva para su existencia, de manera que ellos son los llamados a proponer sus aspiraciones.

Los sanpredrinos por ejemplo, a pesar del fuerte impacto de la sociedad mayor, coinciden en conservar su identidad a toda costa, siendo ellos beneficiarios de toda gestión que se realice en su pueblo. De acuerdo a un estudio realizado recientemente, ellos quieren, en sus palabras:

Que el turismo traiga realmente progreso a los atacameños y no solo a los afuerinos. Por lo que todas las agencias de turismo y las hostales deberian ser administrados por atacameños.

Que exista más educación en San Pedro, que la comuna tenga un liceo y así los niños no se separarían tan jóvenes de sus familias.

Que San Pedro tenga médico para que las guaguas puedan nacer acá y no en Calama. Porque si no, no hay atacameños, son todos calameños.

Que las empresas mineras contraten sólo atacameños. ${ }^{(139)}$

Aunque, sin duda, éste es un aspecto muy parcial de sus aspiraciones, esta claro que ellos quieren seguir siendo atacameños, dentro de los marcos de una idea de progreso que no los margine de la sociedad mayor.

De otro lado, si volvemos la mirada hacia una comunidad con una historia totalmente diferente, que no ha sufrido la presión de afuerinos urbanos de la manera que San Pedro, como es el caso de Toconce, notaremos que su mayor aspiración es poder volver a contar con la cantidad de agua necesaria para sus cultivos y los pastos para el forraje. ${ }^{(140)}$ Desde luego, una educación para sus hijos es una necesidad sentida por todos los pueblos originarios, pero con estos dos mínimos y muy parciales ejemplos, queremos remarcar las diferentes percepciones en la idea del progreso que cada pueblo puede tener, lo que por cierto, incide en su propia valoración y en la necesidad de seguir existiendo. 
Sin duda que el tema de las identidades locales por su complejidad en esta región, desborda cualquier aproximación parcial. Sin embargo, la trama de estas múltiples situaciones permite asegurar que al menos cada pueblo tiene su propia autopercepción, su manera de buscar soluciones, su manera de hacer las cosas, en definitiva, su propia identidad, la que implica procesos sociales de incorporación y de exclusión, valores manifestados en formas culturales originales que integran un campo de acción y de comunicación persistentemente ratificado $y$ en el que los procesos de continuidades y cambios estan articulados dialécticamente. $^{(141)}$

Desde la perspectiva antropológica, creemos que una forma de estudiar el problema es una recopilación sistemática de la oralidad, un tipo de texto polivalente y multifacético, que integra todas las dimensiones vivenciales e históricas y es susceptible de ser estudiado multidisciplinariamente. Finalmente, nos parece que el tema de las identidades, por definición, será siempre abordado parcialmente, dado su caracter de proyecto inacabado, de construcción social siempre dinámico. Sólo hemos ofrecido una ventana al problema a través del tiempo. $^{(142)}$

- Bibliografía

Adán Leonor; Mauricio Uribe, Pilar Alliende y Nuriluz Hermosilla

1997 "Entre el Loa y San Pedro: nuevas Investigaciones Arqueológicas en Caspana". Actas del XIII Congreso de Arqueología Chilena, Universidad de Antofagasta, Antofagasta

Aldunate, Carlos

1993 Arqueología en el pukara de Turi". en Actas del XII Congreso Nacional de Arqueología

Chilena", Tomo II. Boletín 4 Museo Regional de la Araucanía: 61-78, Temuco.

Aldunate, Carlos y Victoria Castro

1981 Las chullpa de Toconce y su relación con el poblamiento altiplánico en el Loa Superior, Período Tardío. Eds. Kultrun, Santiago.

Aldunate, Carlos; Juan. Armesto; Victoria Castro y Carolina Villagran

1981 "Estudio etnobotánico en una comunidad precordillerana de Antofagasta: Toconce"; Boletín del Museo Nacional de Historia Natural 38: 183-223; Santiago.

Aldunate, Carlos; José Berenguer y Victoria Castro

1982 "La función de las chullpa en Likan". Actas del 7o. Congreso de Arqueología de Chile. Eds. Kultrun, Santiago.

Aldunate, Carlos; José Berenguer; Victoria Castro; Luis Cornejo; José Luis Martínez y Carola Sinclaire

1986 Cronología y asentamiento en la región del Loa Superior. Universidad de Chile, Departamento de Investigación y Bibliotecas, Santiago.

Barnadas Joseph

1973 Charcas 1535-1565. Orígenes históricos de una sociedad colonial. Centro de Investigación y promoción del campesinado (CIPCA), La Paz.

Barth Fredrik

1976 Los Grupos Etnicos y sus Fronteras. La organización Social de las diferencias culturales. Fondo de Cultura Económica, México.

Barthel, Thomas S.

1986 [1957] "El agua y el festival de Primavera entre los atacameños". Allpanchis 28, año XVIII:147-184; Cuzco.

Bennett Wendell

1946" The Atacameño". Handbook of Southamerican Indians. J.Steward ed. Bulletin 143, vol.ll: 599 ?618. Washington, D.C.

Berenguer, José; Carlos Aldunate y Victoria Castro

1984 "Orientación orográfica de las chullpas en Likan: la importancia de los cerros en la fase Toconce". Simposio Culturas Atacameñas:175-220; U. del Norte, Antofagasta.

Bibar Jerónimo de

1966[1558] Crónica y Relación Copiosa y Verdadera de los Reinos de Chile. Fondo Histórico y Bibliográfico José Toribio Medina, Santiago, Chile.

Bittmann Bente

- 1979 " Cobija y Alrededores en la Época Colonial ( 1600-1750). Actas del VII Congreso de Arqueología de Chile Volumen II:327-356. Ediciones Kultrun, Santiago.

- 1983 "Cobija: Panorama etnohistórico en relación a los informes del Dr. José Agustín de Arze". Chungara 10:147 - 154. Arica.

- 1984 El Programa Cobija: Investigaciones Antropológico - multidisciplinarias en la Costa Centro Sur Andina: Notas Etnohistóricas". En Contribuciones a los Estudios de los Andes Centrales :101-149. Shozo Masuda ed., Universidad de Tokio, Tokio.

- 1986 Recursos naturales renovables de la costa del norte de Chile: modos de obtención y uso" en Etnografía e historia del mundo andino. Continuidad y cambio : 269-334, Shozo Masuda ed., 
Universidad de Tokio, Japón.

Bordes Pedro

1960 Métodos Misionales en la Cristianizacion de América. Siglo XVI. Consejo Superior de Investigaciones Científicas. Departamento de Misionología Española. Madrid.

Bouysse Cassagne Therese

1975 Pertenencia étnica, status económico y lenguas en Charcas a fines del siglo XVI". En Tasa de la Visita General de Francisco de Toledo, Cook ed. Universidad Nacional Mayor de San Marcos, Lima.

Cañete y Dominguez ,Pedro Vicente

1974 (1791) " Del Partido de Atacama". Con Notas y Bibliografía de Horacio Larraín. Norte Grande vol. I, (2):243?251, Santiago.

Cárdenas, Ulises

2001 Entre el Tolar y el Pajonal. Percepción ambiental y uso de plantas en la comunidad atacameña de Talabre, II región, Chile. Estudios Atacameños 16 - 1998: 251-282, San Pedro de Atacama.

Casassas, José Maíia

1974 La región atacameña en el siglo XVII, Universidad del Norte, Antofagasta.

Castro, Victoria

- 1986 "An approach to the Andean Etnozoology: Toconce". Cultural Attitudes to Animals...Vol. II:

1-17. Allen \& Unwin. Londres.

- 1988a "Entrevista a un yatiri de la localidad de Toconce, II Región, Chile (Agosto 1979)." Plantas Medicinales de Uso Comun en Chile. (Farga,Lastra y Hoffmann eds). Tomo III:117-119.

- 1988b "Terrazas agrícolas: una vieja tecnología para las nuevas generaciones". Creces 2:7-12, Santiago.

- 1991. " Un proceso de extirpación de idolatrias en Atacama, siglo XVII". Historia y Cultura XX: 131- 150. Sociedad Bolivariana de Historia, Ed. Don Bosco, La Paz.

- 1997 Huacca Muchay. Evangelización y religión andina en Charcas, Atacama la Baja. Tesis de Magister en Etnohistoria, Facultad de Filosofía y Humanidades, Universidad de Chile

- 1998 La dinámica de las identidades en la subregión de río Salado, Provincia EI Loa, II Región. En Actas del I Encuentro Nacional Interinstitucional de Investigadores de Identidades Culturales: 5 50. Programa de Desarrollo de Identidades Culturales. M. Dannemann editor, Departamento de Investigación y Desarrollo, Universidad de Chile, Santiago.

Castro, Victoria; José Berenguer y Carlos Aldunate

1979 "Antecedentes de una interacción altiplano-área atacameña durante el período

Tardío:Toconce". Actas del VII Congreso de Arqueología de Chile, vol. II: 477?498; Eds. Kultrun, Santiago.

Castro, Victoria; Carlos Aldunate y José Berenguer

1984 "Orígenes altiplánicos de la fase Toconce". Estudios Atacameños 7: 209-235 Universidad del Norte, San Pedro de Atacama.

Castro Victoria y Varinia Varela

1992 " Así sabían contar". Oralidad 4: 16- 27. La Habana.

Castro Victoria y Varinia Varela eds.

1994 Ceremonias de Tierra y Agua. Ritos Milenarios Andinos. Imprenta Kuppenheim, Santiago.

Castro, Victoria, Fernando Maldonado y Mario Vásquez

1993 Arquitectura del "Pukará" de Turi. Actas del XIII Congreso Nacional de Arqueología Chilena, Antofagasta.

Castro Victoria y Francisco Gallardo

1995-96 "El Poder de los Gentiles". Revista Chilena de Antropología 13:79-98, Universidad de Chile, Santiago.

Castro Victoria y José Luis Martínez

1997 "Poblaciones indígenas de la Provincia de El Loa" Culturas de Chile. Etnografía. Editorial Andres Bello. Santiago.

Castro Victoria y Mauricio Uribe

2001 Dos "dados" de Caspana. El juego de la Pichica y el Dominio Inka en el Loa Superior. Actas del XV Congreso de Arqueologií Chilena (MS. enviado a publicación). Arica.

Cieza De León Pedro

1945 (1553) La Crónica del Perú. Ed. Espasa Calpe. Buenos Aires.

Delano, Priscilla

1982 Aspectos socioeconómicos de una comunidad del norte grande: Caspana; Tesis para optar al grado de Licenciado en Antropología Social, Facultad de Humanidades, Universidad de Chile, 
Santiago.

Díaz De Guzmán Rui

1835[1612] Historia del Descubrimiento, Población y Conquista de las Provincias del Río de la Plata Imprenta del Estado, Buenos Aires.

Espinoza Waldemar

1980 "Los fundamentos linguísticos de la etnohistoria andina y comentarios en torno al Anonimo de Charcas de 1604". Revista Española de Antropología 10:149-181, Madrid.

Fernández Jorge

1978 " Los Chichas, los lipes y un posible enclave de la cultura de San Pedro de Atacama en la puna limítrofe argentino - boliviana". Estudios Atacameños 6:19-35. San Pedro de Atacama.

Galdós Guillermo

1985 "Interrelaciones estructurales en la costa surperuana". Diaáogo Andino 3: 47-58. Departamento de Historia y Geografía, Universidad de Tarapacá, Arica.

Gómez, Carlos

1980 La comunidad campesina indigena del Loa superior. Tesis de grado para optar al grado de Licenciado en Antropología social. Facultad de Ciencias Humanas, U. de Chile, Santiago.

Gómez Parra, Domingo

1976 "Narraciones tradicionales de Socaire"; Cuadernos de Filología 5: 47-68, Antofagasta.

Gómez Parra, Domingo

1979 "Siete relatos populares peineños". Cuadernos de Filología 10:37-44, Antofagasta.

Gómez Parra, Domingo

1980 "Veinticuatro relatos populares toconceños"; Cuadernos de Filología 12: 80-108, Antofagasta.

Gómez Parra, Domingo

1981-82 "Los pueblos andinos de la Segunda Región y su alimentación tradicional". Cuadernos de Filología 15;16:49-80, Antofagasta.

Gómez Parra, Domingo

1982 "Narrativa popular atacameña; Habitat. Cultura. Corpus". Cuadernos de Filología 17:1-110, Antofagasta.

Grebe Ester

1984 "Etnozoología andina: concepciones e interacciones del hombre andino con la fauna altiplánica". Estudios Atacameños 7: 455 - 472. San Pedro de Atacama.

Hanson, Earl

1926 "Out-of-the-world villages of Atacama". Geographical Review vol. 16:365-377; Nueva York.

Hidalgo, Jorge

- 1978 "Incidencias de los patrones de poblamiento en el cálculo de la población del Partido de Atacama desde 1752 a 1804. Las revisitas ineditas de 1787-1792 y 1804". Estudios Atacameños 6: 53-111, San Pedro de Atacama.

- 1981 "Culturas y Etnias Protohistóricas: Área Andina Meridional". Chungara 8: 209-254. Arica.

- 1982 "Fechas coloniales de fundación de Toconao y urbanización de San Pedro de Atacama" Chungara 8:255-264; Arica.

- 1982 Fases de la rebelión indígena de 1781 en el Corregimiento de Atacama y esquema de la inestabilidad política que la precede. 1749-1781. Anexo: Dos documentos inéditos contemporáneos. Chungará 9:192-46, Universidad de Tarapacá, Arica.

- 1983 "Dos documentos inéditos y un mapa de Cobija: informes del comisionado Dr. José Agustín de Arze, 1786-1787". Chungará 10: 139-146, Arica.

- 1984 a "Descomposición cultural de Atacama en el siglo XVIII: lengua, escuela, fugas y complementariedad ecológica"; Simposio Culturas Atacameñas:221-249, 44 Congreso de Americanistas, Universidad del Norte, Antofagasta.

- 1984 b "Complementariedad ecológica y tributo en Atacama:1683-1792". Estudios Atacameños 7: 422-42. Universidad del norte, San Pedro de Atacama.

- 1985 a "Carta del Obispo de Arequipa sobre los indios del corregimiento de Arica: 1620-1638. Cuatro documentos inéditos". Chungará 15: 77 -98, Universidad de Tarapacá, Arica.

- 1985 b "Ecological complementarity and tribute in Atacama: 1683-1792". En Masuda.S, I. Shimada \& C. Morris, eds. Andean Ecology and Civilization: 161-184. Tokyo.

- 1986 Indian Society in Arica, Tarapacá and Atacama, 1750 - 1793, and its response to the rebellion of Tupac Amaru. A thesis presented for the Deree of Ph.D. in t University of London 
Hidalgo Jorge; Nancy Hume; María Marsilli y Rebeca Correa (transcriptores)

1992 (1683) Padron y Revisita de Atacama del Corregidor Alonso de Espejo, ordenada por el virrey Duque de La Palata. AGNA, Sala IX 7:7:1, 52 fs. (A?o 1683). Estudios Atacameños 10:79-124, San Pedro de Atacama.

Hidalgo, Blas

1992. Organización Social, Tradición y Aculturación en Socaire, una aldea atacameña. Memoria para optar al título de Antropológo Social. Universidad de Chile. Facultad de Ciencias Sociales. Departamento de Antropología. Santiago.

Larraín Horacio

1991 " Limpia de Canales de Toconce: Descripción de una ceremonia - faena tradicional". Hombre y Desierto 5:3-19, Antofagasta.

Larraín Horacio y Eric Ross

1988 "Historia y Evolución de los comites de Artesanos en pueblos situados en el hinterland de la II Región, Antofagasta." Hombre y Desierto 2:89-104. Antofagasta.

Latcham Ricardo

1910 "¿Quiénes eran los changos?". Anales de la Universidad de Chile 126:377-439, Santiago.

1938 Arqueología de la Región Atacameña. Prensas de la Universidad de Chile, Santiago.

Lizarraga Reginaldo de

1987[1594-1608] "Descripción del Perú, Tucumán, Río de la Plata y Chile. Edición de Ignacio Ballesteros, Historia 16, Madrid.

López Clara

1988 Estructura económica de una sociedad colonial. Charcas en el siglo XVII, CERES, La Paz.

Lozano Machuca Juan

1885(1581) "Carta del Factor de Potosí al virrey del Perú, en donde se describe la Provincia de los lipes". Relaciones Geográficas de Indias, Perú, T. II, Apendice III. Ministerio de Fomento, Madrid.

Lumbreras Luis Guillermo

1974 " Los reinos post Tiwanaku en el Area Altiplánica". Revista del Museo Nacional de Lima

40:55-87, Lima.

1978 "Definición del Área Andina: Centro Sur Andino. Documento base N. 3" .Ms. Proyecto Regional de Patrimonio Cultural Andino. UNESCO.

Llagostera, Agustín

1982 Tres dimensiones en la conquista prehistórica del mar. Acatas del VIII Congreso de Arqueología Chilena: 217 -245. Altos de Vilches, 1979. Ediciones Kultrun, Santiago

Martínez, Jose Luis

- 1985 a "Adaptación y cambio en los atacameños. Los inicios del período colonial, siglos XVI y XVII". Andes: 9-25; Santiago.

- 1985 b "La formación del actual pueblo de Toconce. Siglo XIX"; Chungará 15:99-124; Arica.

- 1985 c Información sobre el comercio de pescado entre Cobija y Potosí, hecha por el Corregidor de Atacama, Don Juan de Segura (19 de Julio de 1591)" Cuadernos de Historia 5: 161-171. Facultad de Filosofía y humanidades, Universidad de Chile, Santiago.

- 1988 "Dispersión y movilidad en Atacama Colonial". Encuentro de Etnohistoriadores. Serie Nuevo Mundo Cinco Siglos N.1: 53-69. Facultad de Filosofía y Humanidades, Universidad de Chile, Santiago.

- 1990 a "Asentamientos y acceso a recursos en Atacama (s. XVII)"; Serie Nuevo mundo: cinco siglos 5: 13-62 Departamento de Ciencias Históricas, U. de Chile, Santiago.

- 1990b "Interetnicidad y complementariedad en el Altipláno meridional". Andes N.1: 11-30, Salta.

- 1992 "Acerca de las Etnicidades en la Puna Arida en el siglo XVI". Etnicidad, Economía y Simbolismo en los Andes: 35 -65. II Congreso Internacional de Etnohistoria, Coroico.

- 1995 Papeles distantes, palabras quebradas. Las informaciones sobre lipes en el siglo XVI. Espacio, étnias, frontera. Atenuaciones políticas en el sur del Tawantinsuyu, siglos XV - XVIII. Presta A.M. editor: 285 - 317, Ediciones ASUR № 4, Sucre.

- 1997 Pueblos del Chañar y el Algarrobo. Los Atacamas en el siglo XVII. DIBAM. Centro de Estudios Diego Barros Arana, Santiago.

Masuda, Shozo; I. Shimada y C. Morris, eds. 1985 Andean Ecology and Civilization. University of Tokyo Press, Tokio.

Matienzo,Juan

1967 (1567) Gobierno del Perú. Ed. a cargo de G. Lohmann Villena. Travaux de I'Institut Francais d' Etudes Andines. Paris - Lima. 
Mercado Claudio, P. Rodríguez y M. Uribe

1997 Pa' que coman las Almas. La Muerte en el Alto Loa. LOM Ediciones, Santiago.

Miranda Pablo

1998 Julian Colamar Recuerda. Visiones de Caspana. LOM Ediciones, Santiago.

Morales, Hector

1997 Pastores transhumantes del fin del mundo. Memoria para optar al título de Antropológo Social. Departamento de Antropología, Facultad de Ciencias Sociales, Universidad de Chile.

Mostny Grete

1952 Una tumba de Chiuchiu. Boletín del Museo Nacional de Historia Natural, XXVI(1):1 55, Santiago.

Mostny, Grete; Fidel Jeldes y Raul González

1954 Peine, un pueblo atacameño, Instituto de Geografía, Universidad de Chile, Santiago.

Mostny Grete y Hans Niemeyer

1983 Arte Rupestre Chileno. Serie El Patrimonio Cultural Chileno. Publicación del Departamento de Extensión Cultural del Ministerio de Educación, Santiago.

Munizaga, Carlos y Hugo Gunckel

1958 "Notas etnobotánicas del pueblo atacameño de Socaire, o etnobotánica de Socaire" Publicaciones del Centro de Estudios Antropológicos 5, Universidad de Chile, Santiago.

Murra, John

1964 "Una apreciación etnológica de la Visita" en Visita hecha a la Provincia de Chucuito por Garci Diez de San Miguel el a?o 1567 :421-442. Ediciones de la Casa de la Cultura del Perú, Lima.

1972 "An archaeological "reestudy" of andean ethnohistorical account". American Antiquity. Vol. 28(1): 1-4.

Núñez, Marie Karoline

2000 Movimientos y voces en Peine. Tesis para optar al grado de Licenciada en Antropología Social y al Título de Antropológo Social. Universidad Academia de Humanismo Cristiano, Escuela de Antropología, Santiago.

2001 "Saber andino manejo de recursos y transformaciones". Estudios Atacameños 16: 283-292, San Pedro de Atacama.

Núñez, Lautaro

- 1968 Subárea Loa - Costa Chilena desde Copiapó a Pisagua". Actas del XXXVII Congreso Internacional de Americanistas:145-182, Buenos Aires.

- 1976 Geoglifos y tráfico de caravanas en el desierto chileno. En, J.M. Casassas (ed.): Homenaje al R. P. Gustavo Le Paige S.J., Universidad del Norte, Antofagasta.

- 1979 Comentario sobre el Area Centro Sur Andina". Departamento de Arqueología, Universidad del Norte, Antofagasta.

- 1985 "Petroglifos y tráfico en el desierto chileno. Estudios en Arte Rupestre.(C. Aldunate, J. Berenguer \& V. Castro eds.):243-264. Museo Chileno de Arte Precolombino, Santiago.

- 1992 Cultura y Conflicto en los Oasis de San Pedro de Atacama. Editorial Universitaria, Santiago.

Núñez Lautaro; Patricio Núñez y Vjera Zlatar

1975 "Relaciones prehistóricas trasandinas entre el N.O. argentino y Norte de Chile (Período Cerámico)". Serie documentos de Trabajo 6: 1 - 25. Antofagasta.

Núñez, Lautaro y Tom Dillehay

1978 Movilidad giratoria, Armonia Social y Desarrollo en los Andes Meridionales: Patrones de Tráfico e Interacción Económica. Universidad del Norte, Antofagasta.

Oviedoy Valdes Gonzalo

1855[1547] Historia General Natural de las Indias, Islas y tierra Firme del Mar Océano Imprenta de la Real Academia de la Historia, Madrid.

Pollard Gordon

1970 The Cultural Ecology of Ceramic - Stage Settlement in the Atacama Desert. Columbia University, Doctoral Thesis published on demand by University Microfilm International, Ann Harbor, Michigan.

Pease Franklin

s/f. "Etnohistoria andina. Problemas de fuentes y Metodología". Ms. (Mecano) Pontificia Universidad Católica de Lima. 31 pp., Lima.

Polo De Ondegardo Juan

1916[1571] Informaciones acerca de la Religión y Gobierno de los Incas. Libros y Documentos referentes a la historia del Perú. Coleccion de Vargas Ugarte. Lima. 
Rivera Francisco

1993 Estudio de la Autopercepción de la marginalidad en San Pedro de Atacama. Informe final de Práctica Profesional. Carrera de Antropología . Facultad de Ciencias Sociales. Universidad de Chile. Santiago.

Romo, Marcela

- 1998 Percepción y Representación del Ambiente en un Grupo de Pastores. Memoria para optar al Título de Antropológa Social. Departamento de Antropología, Facultad de Ciencias Sociales, Universidad de Chile, Santiago.

- 2001 Pastores del Sur Andino. Percepción y representación del Ambiente. Estudios Atacameños 16 (1998): 209-232, San Pedro de Atacama.

Romo, Marcela, Victoria Castro, Carolina Villagrán y Claudio Latorre.

2001 La transición entre las tradiciones del desierto y las quebradas altas del Loa Superior. Etnobotánica del valle del Río Grande, Segunda Región, Chile. En prensa, Chungará 31 (2), Arica.

Rostworowski María

1986 "La Región del Colesuyu". Chungará 16-17:127-135, Arica.

Saignes Thierry

- 1985 Algún día todo se andara. Los movimientos étnicos en Charcas (siglo XVII)". Revista Andina 3 (2):425 - 450. Lima.

- 1986 En busca del poblamiento étnico de los Andes bolivianos. Siglos XVI y XVII". Avances de Investigación 3 : 5-47. La Paz.

Salcamayhua Juan Santa Cruz Pachacuti Yamque

1968[1608] Relación de Antiguedades deste reyno del Perú. B.A.E. Tomo 209, Madrid.

Sanhueza Cecilia

1991 Orígenes y Desarrollo de la Arrieria Indígena Colonial en Atacama. Siglos XVI y XVII. Tesis para optar al grado de Licenciado en Historia. Pontíficia Universidad Católica, Santiago.

Schiapacasse Virgilio, Victoria Castro y Hans Niemayer

1989" Los desarrollos regionales en el Norte Grande (1000 a 1400 D.C.)en Hidalgo J. et al. eds. Culturas de Chile. Prehistoria: 181-220. Editorial Andres Bello, Santiago.

Serracino Jorge

1985 "Creencias, organización Social y Economía en Caspana Indígena. La Limpia de Canales". Corporación Cultural y de Turismo. Calama.

Szemiñski, Jan

1997 Ika yunka + Lima yunka = Inca. Un ejemplo de transformaciones étnicas en el siglo XVI. Arqueología, Antropología e Historia en los Andes. Homenaje a María Rostworowski: 335-352. Instituto de Estudios Peruanos, Lima.

Tarrago, Myriam

1989 Contribución al conocimiento arqueológico de las poblaciones de los oasis de San Pedro de Atacama en relación con los otros pueblos puneños, en especial el sector septentrional del valle calchaqui. Tesis Doctoral Universidad de Rosario, Rosario

Tellez Eduardo

1984 "La guerra atacameña del siglo XVI: Implicancias y trascendencia de un proceso de resistencia indígena en el despoblado de Atacama". Estudios Atacameños 7: 399-421. San Pedro de Atacama.

Tellez Eduardo y Osvaldo Silva

1989 "Atacama en el siglo XVI. La Conquista Hispana en la Periferia de los Andes Meridionales". Cuadernos de Historia 9: 45 - 69. Universidad de Chile, Santiago.

Torero, Alfredo

1970" Linguística e Historia de la Sociedad Andina". Universidad Nacional Agraria. Anales Científicos Vol 8, N. 3-4:231-264, Lima.

Thomas Carlos

1978 Estudio Arqueológico del poblamiento prehispánico tardío de ChiuChiu". Revista Chilena de

Antropología 1: 85-104, Santiago.

Valenzuela Jaime

1988 " Estudio morfológico de artesania tradicional en cerámica de Río Grande" . Hombre y Desierto 2:105-114.

Vaisse, Emilio; F. Hoyos y A. Echeverría

1896 Glosario de la lengua atacameña. Imprenta Cervantes, Santiago.

Varela Varinia

1992 De Toconce "Pueblo de Alfareros" a Turi " Pueblo de Gentiles". Un Estudio de Etnoarqueología. Tesis para optar al Grado de Licenciado en Antropología con mención en Arqueología. Departamento de Antropología, Facultad de Ciencias Sociales, Universidad de Chile. 
Santiago.

Wachtel Nathan

- 1978 "Hommes d 'au: le probleme uru (XVI-XVII siecle)". Annales E.S.C. 33 (5-6):1126-1161, Paris.

- 1988 "Hombres del Agua: El problema uru. Siglos XVI-XVII". Revista del Museo Nacional de Etnografia y Folklore A?o 1 (1-2) 1984-1988:217-258. La Paz.

- 1990 Le retour des ancetres. Les indiens Urus de Bolivie, XX . XVI siecle. Essai d'Histoire regressive, Editions Gallimard, Paris.

Uribe Mauricio y Leonor Adán

1995 Tiempo y Espacio en Atacama: la mirada desde Caspana. Boletín de la Sociedad Chilena de Arqueología 21, Santiago

Villagrán Carolina y Victoria Castro

1999 Etnobotánica y Manejo ganadero de las Vegas, Bofedales y Quebradas en el Loa superior, Andes de Antofagasta, Segunda Región, Chile. Chungará 29(2): 275 - 304

Villagrán Carolina, Victoria Castro, Gilberto Sánchez, Marcela Romo, Claudio Latorre y Felipe Hinojosa

2001 Etnobotánica del área del Salar de Atacama (Provincia El Loa, Región de Antofagasta, Chile). Estudios Atacameños 16 - 1998: 7 - 106.

Villagrán Carolina, Victoria Castro, Gilberto Sánchez

2001 Etnobotánica y Percepción del Paisaje en Caspana (Provincia El Loa, Región de Antofagasta, Chile). Estudios Atacameños 16 - 1998: 107 - 170.

Villaseca, María de los Angeles

2000 Dos Historias, Un paisaje. Transformación y persistencia en el Alto Loa. Memoria para optar al Título de Antropológa Social, Departamento de Antropología, Facultad de Ciencias Sociales, Universidad de Chile, Santiago.

2001 "Percepción, desecación y revitalización cultural". Estudios Atacameños 16 - 1998: 233- 250., San Pedro de Atacama

- Notas

$1 \quad$ Cfr. Lumbreras, 1978; Núñez L. , 1979; Aldunate y Castro, 1981: 10 - 11.

volver

2 Castro et al., 1984

volver

3 Vid. Bouysse Cassagne, 1975; Galdos, 1985.

volver

$4 \quad$ Saignes 1985: 426-427; 1986: 9.

volver

$5 \quad$ Vid. López 1988:36; Barnadas 1973; Saignes 1986.

volver

6 Cañete y Domínguez, 1974: 243-245; Casassas, 1974: 29-30; Hidalgo, 1984 b: 424; Sanhueza, 1991: 44

volver

7 Oviedo y Valdés, [1547]1855: 247-280; Bibar, [1558]1966: 12.

volver

8 Vid por ejemplo Hidalgo, 1981 y 1982; Aldunate y Castro, 1981; Téllez, 1984; Téllez y Silva, 1989.

volve

9 Castro V., 1998: 5.

volver

10 Ibid.

volver

11 A nivel etnográfico, recientemente hemos planteado una tercera tradición, que hemos llamado de "quebradas altas", que singulariza situaciones de enfasis entre ambas, con un predominio quizá más equilibrado entre estas tradiciones (Romo et al. 2001). Esta nueva caracterización es susceptible de ser aplicada a las situaciones de los pueblos de Río Grande y Caspana. Tal vez para esta última comunidad, pueda retrotraerse a tiempos prehispánicos.

volve 
12 El término Kunza (Ckunsa, Nuestro. Sensu Vaisse et al. 1896:21), para denotar el idioma hablado por los naturales del sector meridional de la Provincia de El Loa, aparentemente es acuñado sólo en el siglo XIX; no conocemos hasta ahora ninguna mención previa a ese nombre.

volver

13 Bouysse Cassagne, 1975; Schiapacasse V., V. Castro y H. Niemeyer, 1989: 185. volver

14 Castro V.; J. Berenguer y C. Aldunate, 1979.

volver

15 Para un estudio en profundidad de este componente arqueológico puede verse: Castro et al., 1979; Aldunate y Castro, 1981; Aldunate C; J. Berenguer y V. Castro, 1982; Berenguer J; V. Castro y C. Aldunate, 1984.

volver

16 Castro V. et al., 1984

volver

17 Castro V., 1997, 1998 volver

18 Vid. Andean Ecology and Civilization, 1985 (Masuda et al., editores) que contiene los resultados de un Simposio realizado a sugerencias del etnológo John Murra con el fin de analizar y profundizar sobre diversos modelos de complementariedad en Andinoamérica. volver

19 Cfr. Núñez y Dillehay, 1978.

volver

20 Schiapacasse et al., 1989:211.

volver

21 Cfr. Schiapacasse et al., 1989:215.

volver

22 Cfr. Ibid.:215-216.

volver

23 Vid. Thomas, 1978.

volver

24 Descripciones exhaustivas de contextos exhumados en estos cementerios en Mostny, 1952 y Núñez, 1968

volver

25 Castro V. et. al., 1984

volver

26 Las chullpas son edificaciones en forma de torres, con muros simples o dobles, hechas de piedra unidas con argamasa o de adobe. Su planta es rectangular, ovalada o circular, con un pequeño vano preferentemente a media altura de uno de los muros; son un indicador altiplánico clave para el período pues se trata de una arquitectura propia de los señorios circumlacustres. Las de Toconce Mallku son muy similares a las del Noreste del Titikaka, que fueron utilizadas como repositorios funerarios. Sin embargo al menos las de Likan se usaron como adoratorios (Vid. Aldunate y Castro, 1981; Aldunate el al., 1982; Berenguer et al., 1984; Castro el al., 1984; Schiapacasse et al., 1989). volver

27 Berenguer et al, 1984. volver

28 Hanson, 1926:377.

volver

29 cf. Pollard, 1970.

volver

30 Núñez, 1976:187. volver

$31 \quad$ Vid Castro 1997

volver

32 Cieza, 1945(1551):257; Matienzo, 1967(1567):129.

volver

33 Cf. Aldunate et al., 1982:129.

volver 
34 Lumbreras, 1974.

volver

35 Torero, 1970

volver

36 Castro, Aldunate y Berenguer, 1984:224-225

volver

$37 \quad$ Tarrago 1989

volver

38 Nuevos aportes pueden verse en Aldunate 1993; Castro et al. 1993; Adan et al. 1995; Uribe y Adan 1995; Castro y Uribe 2001.

volver

39 Lo que sí está claro es que con el Inka, toda Andinoamérica estuvo afecta a situaciones que pudieron alterar las identidades preexistentes. Vease, por ejemplo, Szemiñski, 1997.

volver

40 Las investigaciones arqueológicas en este sector son francamente deficitarias y las inferencias respecto a su población prehispánica por tanto, no descansan sobre el mismo rango de certeza que las anteriormente tratadas. volver

41 Vease Llagostera, 1982

volver

42 Cfr. Schiapacasse et al., 1989:205-207.

volver

43 Mostny y Niemeyer, 1983.

volver

44 Núñez, 1985.

volver

45 Mostny, 1952.

volver

46 Martínez, Jose 1992: 41; 1998 passim

volver

47 Martínez J. : 1992: 48.

volver

$48 \quad$ Ibid. $53-55$

volver

49 Nos referimos particularmente a los trabajos de Casassas, Hidalgo, Martínez y Castro, para el interior de Atacama y a Bittman para el sector de Cobija.

volver

50 Bittmann 1979: 329; 1983: 147

volver

51 Vid. Bittmann 1979: 328-329.

volver

52 Lozano de Machuca (1581) 1885:XXV.

volver

53 Vid. por ejemplo, Lozano de Machuca op.cit.; Murra 1972; Bouysse Cassagne 1975; Wachtel 1978.

volver

54 Cfr. Bittmann 1984:109.

volver

55 Bittmann 1979:339

volver

56 Martínez 1985 c: 164.

volver

57 Bittmann 1979: 339.

volver

58 Lizárraga Descripción del Perú, Tucumán, Río de La Plata y Chile [1594- 1608], 1987:148 ( Ballesteros ed.). Vid Hidalgo 1981: 214. Según Cuneo de Vidal por las manchas rojizas en su piel, derivadas de la ictiofagia, les llamaron "puquinas" o colorados. Casassas 1974:38. En 
lengua quechua, puca, es el vocablo para el color rojo.

volver

59 Cfr.Bittmann 1984:134-135

volver

60 Vid.Bittmann 1984: 122-128

volver

61 Salcaymahua, Joan de Santa Cruz Pachakuti Yamque [1608] 1968:300. Este dato merece ser trabajado de acuerdo a la pregunta de por qué son connotados casi siempre en estos términos los grupos marginales a las grandes etnías y que se dedican a prácticas de caza, pesca y recolección (en definitiva a lo no domesticado); también Matienzo designa como hechiceros a los chuquilas de Chucuito [1557] 1910:179.

volver

62 Galdos 1985: 47

volver

63 Castro V, 1997: 73

volver

64 Libro de Varias Ojas, en Cassasas 1974: 140. Vease Ibid: 41-43. volver

65 Vid. Bittmann 1984:111. volver

66 Vid. Casassas 1974a: 42-43. El Libro de Varias Ojas (LVO), de la parroquía de Chiuchiu, del Archivo Arzobispal de Antofagasta (AAA), está armado a partir de un conjunto de hojas dispersas que pertenecieron a varios libros o cuadernos parroquiales del siglo XVII ( 1611 1698). En 1733, estas hojas fueron ordenadas como Libro, por el parroco de Chiuchiu, maestro Don Bernardo López . (Ibid.:11).

volver

67 Bittman 1984: 110. En todo caso, los apelativos Lacmor y Laicor, parecen tener una cercanía con la lengua " cunza".

volver

68 Vid. Casassas 1974 (LVO) : 126 - 131

volver

69 Vid. Bibar [1558] 1966: 12.

volver

70 Matienzo [1567] 1910 : 179. Wachtel 1988: passim

volver

71 Vid. Martínez 1985c: 165.

volver

72 Murra 1964: 427.

volver

73 Wachtel, 1990

volver

74 1980: 150.

volver

75 Vid. Bouysse Cassagne 1975.

volver

76 Cfr. Bittmann 1984: 108.

volver

77 Sin duda, es totalmente necesario indagar los significados de los distintos nombres indígenas comparativamente, usando los diccionarios referidos a las diferentes lenguas andinas.

volver

78 Padron y Revisita de Atacama del Corregidor Alonso Espejo, 1683:f1v (transcripción paleográfica de Jorge Hidalgo) Estudios Atacameños 10: 79. 1992.

volver

79 Castro V.1991: 138; Probanza de Francisco Otal, 1644: f.16r y 17; f.72r, en Castro, 1997:72 volver

80 Vid. Bittmann 1984: 111

volver 
81 Rostworowski 1986:129. Segun Cuneo de Vidal el termino camanchacos, camanchangos o changos, aludia a una connotación de "espantosos o repugnantes", otorgado por las poblaciones del interior a los pescadores (Casassas 1974: 38). Varios historiadores utilizan las informaciones de Cuneo de Vidal que sin duda son sugerentes; lamentablemente este autor a menudo no señala la procedencia de sus datos.

volver

82 John Murra, 1964

volver

83 Martínez 1990a: 19

volver

84 Carta del Factor de Potosí Juan Lozano Machuca 1581(1885): XXV.

volver

85 Polo de Ondegardo, [1571], 1916: 79-80

volver

86 Vid. Bittmann 1983: 147

volver

87 Latcham 1910: 418, en Bittmann 1986: 322

volver

88 Bibar 1966: 14

volver

89 Ver por ejemplo, Hidalgo 1978 y 1985b; Martínez 1985a, 1988, 1990 a y b, 1997. Castro 1997

volver

90 Ver Sanhueza 1991:19-22

volver

91 Fernández, 1978

volver

92 Martínez 1992: 39

volver

93 Martínez 1992: 37; Cfr. Aldunate y Castro 1981: 59.

volver

94 Sírvanos como un ejemplo, la conocida referencia de Bibar (1966[1558]: 12-13), que refiere el apoyo directo que los chichas prestaron a los indígenas de Atacama La Alta a la llegada de Valdivia y como previamente fueron avisados por indios de Pica y Guatacondo de la proximidad del español y sus gentes.

volver

95 Vid. Martínez 1992: 53

volver

96 Platt 1982: 10, en Martínez 1985b: 110

volver

97 Fernández 1978: 22

volver

98 Pease S/f.: 12. Martínez (1995), ha escrito un sugerente ensayo sobre los Lipes en el siglo $\mathrm{XVI}$.

volver

99 Vid. El conjunto de trabajos de Cassassas, Hidalgo y Martínez en la bibliografía de este escrito.

volver

100 Hidalgo 1984b: 423; 1985b, passim.

volver

101 Martínez 1990 a: 47

volver

102 Ibid: 43

volver

103 Op.cit.: 44.

volver 
104 Hidalgo 1978: 70.

volver

105 En la actualidad, los habitantes del ayllo de Solor señalan que sus ancestros eran originarios de Bolivia. V. Varela, Comunicación personal 1994.

volver

106 Martínez 1990 a: 47.

volver

107 Ibid: 48

volver

108 Vid. Martínez 1988: 59.

volver

109 Aldunate et al. 1986C

volver

110 Díaz de Guzman [1612] 1835: 12.

volver

111 Martínez 1988: 60

volver

112 Castro V. 1992.

volver

113 Vid. Hidalgo 1982 a y b; 1986. Sin duda que este es otro tema que toca directamente el problema de las identidades en sus distintas dimensiones.

volver

114 Martínez 1990 a: 54

volver

115 Castro, 1997.

volver

116 Sensu Borges, 1960

volver

117 Ver Castro V., 1988 b.

volver

118 Ver Larraín y Ross, 1988; Varela 1992.

volver

119 Sanhuiza, 1991.

volver

120 Ver Castro y Martínez, 1997.

volver

121 Estas han sido descritas por varios investigadores. Entre otros, Mostny, 1954; Barthel, 1986, Gómez Parra, 1976 a 1982; Gómez, 1980; Delano, 1982; Larraín, 1988 y 1991; Castro y Varela, 1992, 1994, Varela, 1992; Hidalgo B., 1992.

volver

122 Ver por ejemplo, Munizaga y Gunckel, 1958; Aldunate et al., 1981; Grebe, 1984; Castro V., 1986; Villagran y Castro, 1999; Villagran et al., 2001 a y b.

volver

123 Ver por ejemplo, Castro y Varela, 1992; Castro, 1998.

volver

124 Ver Larraín, 1991; Castro y Varela eds., 1994.

volver

125 Barthel, 1986; Núñez, 1992: 239-240.

volver

126 Ver Mercado et al., 1997; Castro, 1997; Castro y Martínez, 1997; Miranda, 1998. volver

127 San Antonio, es el patrono de los llamos, para los pueblos originarios del norte grande. volver

128 Ver Castro, 1997.

volver 
129 Vease, por ejemplo, los recientes estudios de Cardenas, 2001; Hidalgo B., 1992; Morales, 1997; K. Núñez, 2000, 2001; Romo, 1998 y 2001; Villaseca, 2000 y 2001.

volver

130 Rivera, 1993: 49

volver

131 Ibid.: 50. Una situación diferente a las anteriores la demuestra la comunidad de Ollague, quienes han decidido identificarse como una comunidad "quechuista", diferente de atacameños y aymaras. (Ver Romo, 1998, 2001).

volver

132 Ver Villagran y Castro, 1999.

volver

133 Martínez, 1990:29.

volver

134 Ver Castro y Gallardo, 1995-96.

volver

135 Esta situación especial de Caspana, ha sido documentada para epocas prehispánicas por Uribe y Adán, 1995 y para el presente, por Villagran et al., 2001.

volver

136 Ver Serracino, 1985.

volver

137 Ver Martínez, 1985 a y b.

volver

138 Ver Castro, 1997.

volver

139 Rivera F., 1993:46.

volver

140 Ver Villagrán y Castro, 1999

volver

141 Ver Barth, 1976

volver

142 Este escrito es una contribución a la reflexión de los proyectos Fondecyt 1011006 y 1000148 volver

Resumen | Territorios | Lenguas, territorios e identidades. | Poblaciones, territorios | La población indígena de Atacama según los documentos coloniales | Los habitantes indígenas del puerto de Cobija y costa aledaña. | Los habitantes indígenas del interior de Atacama | Continuidades y transformaciones | Bibliografía | Notas | Versión Completa (Imprimir) 